\title{
Analysis of the Prehistoric Artifact Assemblage of Ceramic and Lithic Artifacts from 41LR351, Lamar County, Texas
}

Timothy K. Perttula

Heritage Research Center, Stephen F. Austin State University

Follow this and additional works at: https://scholarworks.sfasu.edu/ita

Part of the American Material Culture Commons, Archaeological Anthropology Commons, Environmental Studies Commons, Other American Studies Commons, Other Arts and Humanities Commons, Other History of Art, Architecture, and Archaeology Commons, and the United States History Commons

Tell us how this article helped you.

This Article is brought to you for free and open access by the Center for Regional Heritage Research at SFA ScholarWorks. It has been accepted for inclusion in Index of Texas Archaeology: Open Access Gray Literature from the Lone Star State by an authorized editor of SFA ScholarWorks. For more information, please contact cdsscholarworks@sfasu.edu. 


\section{Analysis of the Prehistoric Artifact Assemblage of Ceramic and Lithic Artifacts from 41LR351, Lamar County, Texas}

\section{Creative Commons License}

\section{(c) (1) \&}

This work is licensed under a Creative Commons Attribution-NonCommercial 4.0 International License 


\title{
Analysis of the Prehistoric Artifact Assemblage of Ceramic and Lithic Artifacts from 41LR351, Lamar County, Texas
}

\author{
Timothy K. Perttula
}

\section{INTRODUCTION}

Site 41LR351 was first recorded during the 2005 Texas Archeological Society summer field school on the Stallings Ranch in Lamar County, Texas. This prehistoric site is on a natural knoll (420-430 feet amsl) in the headwaters of Pine Creek, a northward-flowing tributary of the Red River, in the Post Oak Savannah (Figure 1). The site has been excavated by the Valley of the Caddo Archeological Society, and a large prehistoric Caddo ceramic assemblage has been recovered, along with a substantial chipped stone tool and debris assemblage. The analysis of the ceramic and lithic artifact assemblages from the site is the subject of this article.

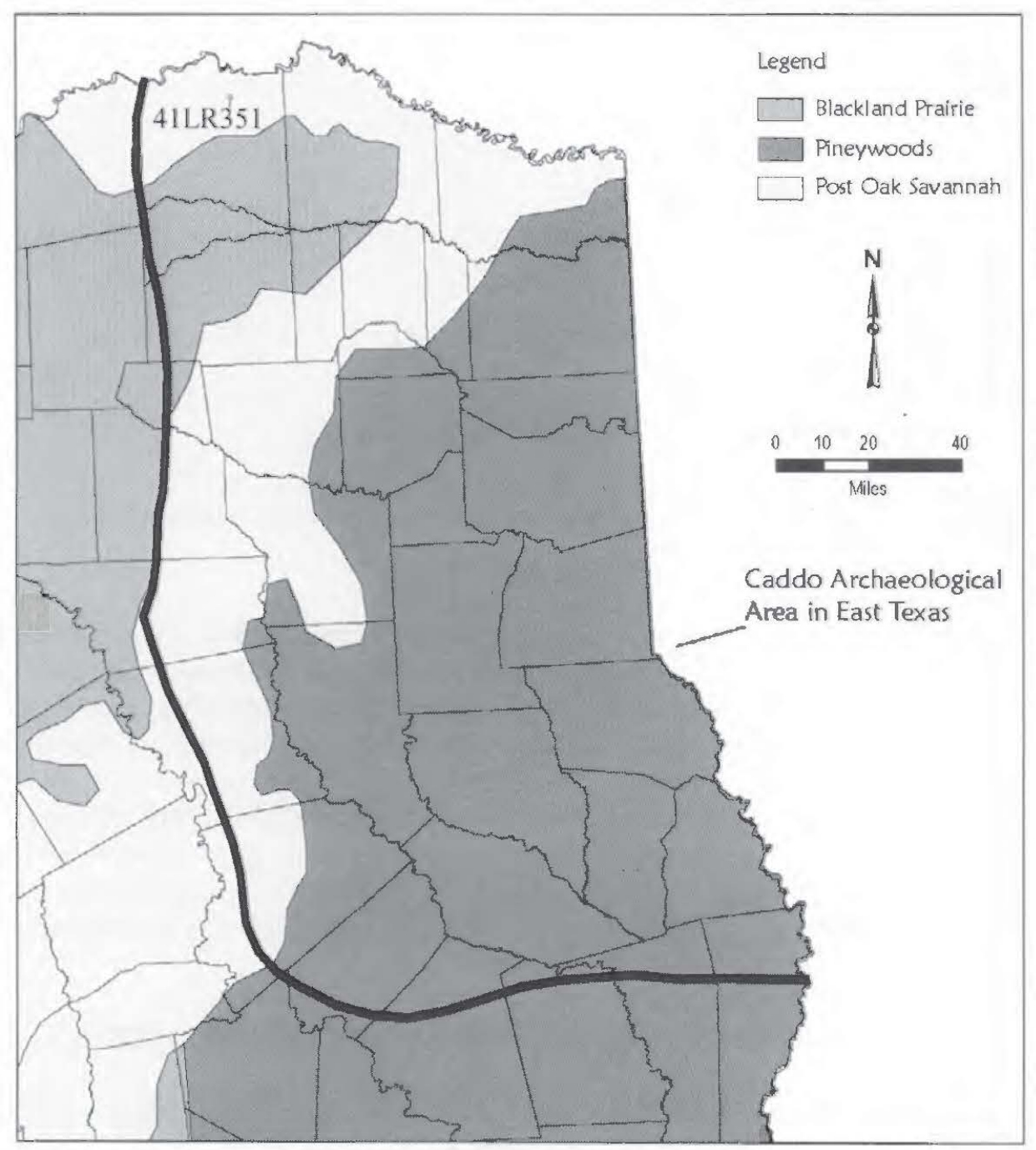

Figure 1. The location of 41LR351 in the Post Oak Savannah of the Caddo Area of Northeast Texas. 


\section{Site Excavations}

The Valley of the Caddo Archeological Society (VoCAS) conducted excavations at 41LR351 between November 10,2007 and October 31,2010, during which time 16 separate $1 \times 1 \mathrm{~m}$ units were excavated in $10 \mathrm{~cm}$ arbitrary levels to depths as great as $90 \mathrm{~cm}$ bs (Figure 2). More excavations are planned by the VoCAS (Gary Sykes, 2012 personal communication).

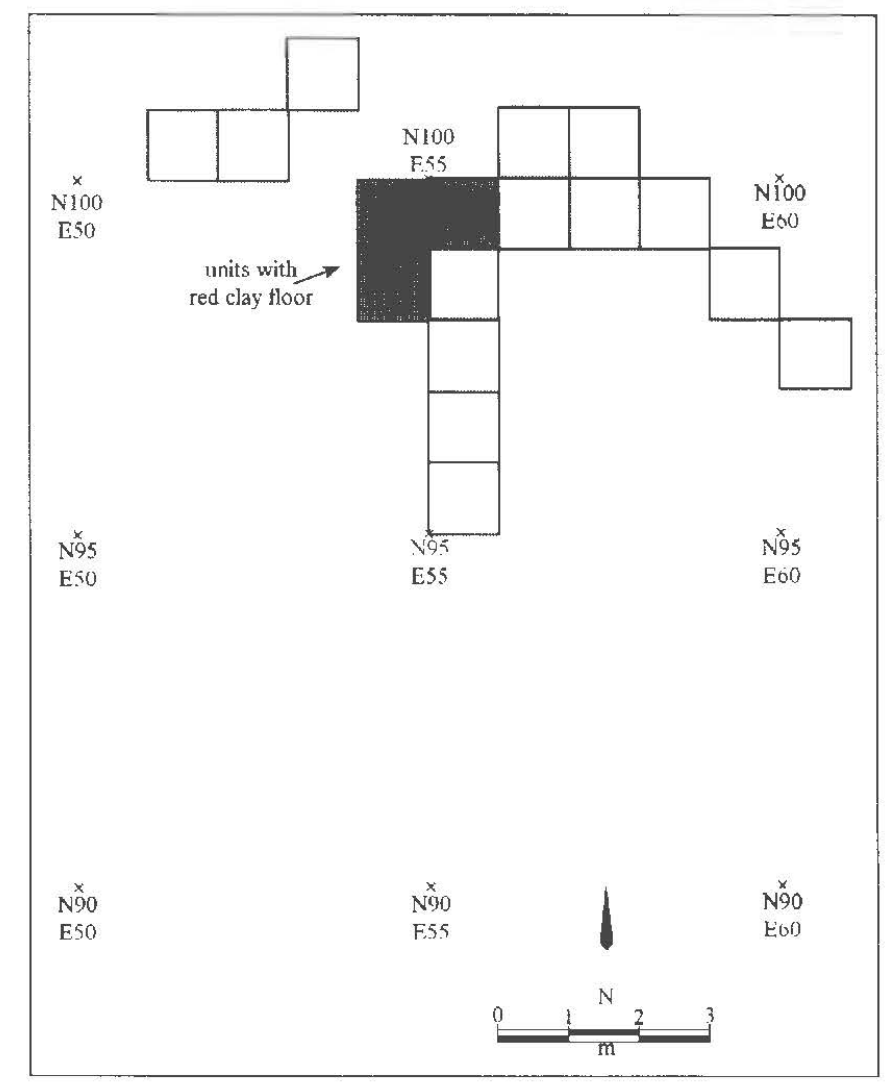

Figure 2. Map of the Valley of the Caddo Archeological Society excavations at 41LR351.

The site is on a natural rise about $1.3 \mathrm{~m}$ in height at its highest point and $12-13 \mathrm{~m}$ in diameter; it is approximately $360 \mathrm{~m}$ west-northwest of the Stallings Ranch site (41LR297) (Bruseth et al. 2009). During the course of the excavations, in addition to quantities of prehistoric ceramic and lithic artifacts, a large quantity of well-preserved daub pieces were recovered, indicating that the excavation units had been placed amidst a burned wattle and daub Caddo house structure. The daub was particularly common at ca. $50 \mathrm{~cm}$ bs in Unit N99 E56 (see Figure 2), along with some burned wood poles. In units N98 E54, N99 E54, and N99 E55, an apparent prepared red clay floor about $5 \mathrm{~cm}$ thick to the structure was exposed between $60-62 \mathrm{~cm}$ bs (see Figure 2). The depth of the apparent house floor suggests either that the floor was in a structure pit, or that the house floor and burned structural materials were covered up and buried with a significant amount (ca. $30 \mathrm{~cm}$ ) of sediments, probably to extinguish the burning.

\section{CERAMIC ASSEMBLAGE AND PROVENIENCE INFORMATION}

The prehistoric Caddo ceramic sherd assemblage from the excavation of 16 units at 41LR351 includes 982 plain and decorated sherds (Table 1). The decorated sherds comprise $16.2 \%$ of the assemblage. The highest densities of ceramic sherds are in N98-E54, N99-E54, N97-E55, and N100-E52, with between 75157 sherds per unit, hut the mean density is 61.4 sherds per $\mathrm{m}^{2}$. 
Table 1. Ceramic sherd assemblage from 41LR351.

\begin{tabular}{llll}
\hline $\begin{array}{l}\text { Provenience } \\
(\mathrm{N}-\mathrm{E})\end{array}$ & $\begin{array}{l}\text { No. of Plain } \\
\text { Sherds }\end{array}$ & $\begin{array}{l}\text { No. of Decorated } \\
\text { Sherds }\end{array}$ & N \\
\hline $95-55$ & 43 & 9 & 52 \\
$96-55$ & 57 & 7 & 64 \\
$97-55$ & 76 & 7 & 83 \\
$97-60$ & 12 & - & 12 \\
$98-54$ & 123 & 34 & 157 \\
$98-55$ & 43 & 8 & 51 \\
$98-59$ & 24 & 7 & 31 \\
$99-54$ & 71 & 29 & 100 \\
$99-55$ & 50 & 8 & 58 \\
$99-56$ & 22 & 5 & 27 \\
$99-58$ & 61 & 13 & 74 \\
$100-51$ & 49 & 11 & 60 \\
$100-52$ & 67 & 8 & 75 \\
$100-56$ & 38 & 4 & 42 \\
$100-57$ & 2 & - & 25 \\
$101-53$ & 85 & 9 & 982 \\
\hline Totals & 823 & 159 & \\
\hline
\end{tabular}

The prehistoric Caddo ceramic sherds occur throughout the archaeological deposits, from $0-90 \mathrm{~cm} \mathrm{bs}$ (Table 2). The highest densities of sherds occur between $30-60 \mathrm{~cm}$ bs $(55 \%)$, with much lower frequencies between $0-30 \mathrm{~cm}$ bs $(25 \%)$ and $60-90 \mathrm{~cm}$ bs $(20 \%)$. The middle depths of the archaeological deposit with the highest densities of ceramic sherds are likely associated with the house floor and the burned structural materials and daub lying above the floor.

Table 2. Depth of Ceramic Sherds at 41LR351.

\begin{tabular}{llllll}
\hline $\begin{array}{l}\text { Depth } \\
\text { (cm bs) }\end{array}$ & $\begin{array}{l}\text { Plain rim* } \\
\text { and body }\end{array}$ & Plain body & Plain base & Decorated rim & $\mathrm{N}$ \\
\hline $0-10$ & - & 46 & 1 & 16 & 63 \\
$10-20$ & - & 43 & 1 & 4 & 48 \\
$20-30$ & 2 & 41 & 5 & 9 & 57 \\
$30-40$ & 4 & 117 & 7 & 36 & 164 \\
$40-50$ & 6 & 82 & 9 & 19 & 116 \\
$50-60$ & 9 & 67 & 2 & 16 & 94 \\
$60-70$ & 2 & 47 & 4 & 13 & 67 \\
$70-80$ & 3 & 64 & 3 & 1 & 56 \\
$80-90$ & 1 & 6 & 41 \\
\hline
\end{tabular}

*includes loop handle sherd. Note: number of sherds by level is based on units where level could be ascertained from the labeled artifact bags.

The plain to decorated sherd ratio (P/DR) is 5.18 at 4 ILR351. By way of comparison, the P/DR at the Stallings site (41LR297), across a small tributary to Pine Creek from 41LR351, is 14.3:1 (Perttula 2008a; see also Bruseth et al. 2009:Figure 1). The high P/DR ratio at the Stallings site indicates that the assemblage in this pre-A.D. 1150 Caddo occupation was dominated by plain ware vessels and vessels with decoration 
confined almost exclusively to a small portion of the upper part of the vessel, but this tendency had changed by the time 4II.R351 was occupied, which was apparently sometime after ca. A.D. 1100.

Pre-A.D. 1200 Caddo sites in the lower Red, middle Sabine, and Neches-Angelina River basins have P/DR values between 2.97-4.80:1 (Perttula 2004:390; Bruseth and Perttula 2006). Closer to 4 LR351, at the Ray site (4IL.R I35), thought to have been principally occupied between ca.A.D. 800-1000 by Bruseth et al. (2001:212), the P/DR value is 56.6:1. At the slightly later prehistoric Caddo component (ca. A.D. 1000-1250) at the Sam Kaufman/Roitsch site (4IRR16) on the middle reaches of the Red River-specifically the East Mound excavations - the P/DR in the ceramic assemblage is 4.8.6:1 (Skinner et al. 1969: Tables 5 and 6), almost identical to the P/DR at 41LR351.

\section{Methods of Ceramic Analysis}

Detailed analysis of the decorated and plain ceramic sherds from 41LR351 is based on differences in temper, type of sherd (i.e., rim, body, or base), rim and lip form (cf. Brown 1996:Figure 2-12), decoration (if present), surface treatment (smoothing, burnishing, or polishing; see Ricc 1987), and firing conditions (cf. Teltser 1993). A sample of sherd cross-sections were inspected macroscopically and with a 10X hand lens to determine the character of the paste and its inclusions. Determining the firing conditions is based on the identification of the firing core in the sherd cross-sections and the identification of oxidation patterns as defined in Teltser (1993:535-536 and Figure 2a-h).

More specifically, the lollowing attributes were employed in the analysis of the vessel ceramics: (a) temper, the deliberate and indeterminate materials found in the paste (Rice 1987:411), including a variety of tempers (grog or crushed sherds, burned bone, hematite, and burned mussel shell) and "particulate matters of some size;" (b) although most of the sherds are small and thus from indeterminate vessel forms, where sherds were large enough, vessel form categories includc open containers (bowls and carinated bowls) and restricted containers, including jars and bottles. Other form attributes include rim profile (outflaring or everted, dircct or vertical, and inverted) and lip profile (rounded, flat, or folded to the exterior). Base shape was recorded if possible. Observations on ceramic sherd cross-sections permit consideration of oxidation patterns (Teltser 1993:Figure 2), namely the conditions under which a vessel was fired and then cooled after firing. Finally. wall thickness was recorded in millimeters $(\mathrm{mm})$, using a vernier caliper, along the mid-section of the sherd.

With respect to interior and exterior surface treatment on the sherds, the primary methods of finishing the surface of the vessels includes smoothing and burnishing, and polishing, although a few sherds may still have scraping marks from initial surface treatment work by the potter. Smoothing creates "a fincr and more regular surlace... [and] has a matte rather than a lustrous surface" (Rice 1987:138). Burnishing creates an irregular lustrous finish marked by parallel facets left by the burnishing tool (perhaps a smoothed pebble or bone). A polished surface treatment is marked by a uniform and highly lustrous surface finish, done when the vessel is dry, but without "the pronounced parallel facets produced by burnishing leather-hard clay" (Rice 1987:138).

Decorative techniques present in the 41LR351 ceramic sherd collection include engraving, slipping, incising, punctating, and appliqued, and on certain sherds, combinations of decorative techniques (i.e., incised-punctated) created the decorative elements and motifs. Engraving was done with a sharp tool when the vessel was either leather-hard or after it was fired, while the other decorative techniques were executed with tools (incising or punctating with wood or bone sticks or dowels) or fingers (fingernail punctating and the creation of appliqued strips) when the vessel was wet or still plastic. 


\section{Decorated Sherds}

The decorated sherds from 41 LR35I are represented by 49 rims and 110 body sherds. The decorated sherds are readily separated into fine wares ( $n=60,37.8 \%$ of the decorated sherds) or utility wares $(n=99$, $62.3 \%$ of the decorated sherds), following the distinctions discussed by Schambach and Miller (1984) at the Cedar Grove site in the Great Bend area in southwestern Arkansas. These distinctions include apparent differences in temper, surface treatment, vessel forms, and decorative methods between the two wares. Utility wares generally are jars and simple bowls used for the cooking and storage of fonds, have a coarse temper, and lack burnishing, polishing, or slipping on interior and exterior vessel sherd surfaces. Such vessel sherds are decorated with brushing, incising, punctations (tool, cane, or fingernail), and appliqued elements, either by themselves or in combination with one or more of these decorative methods (see Perttula et al. 1995; Schambach and Miller 1984; Suhm and Jelks 1962). Fine wares, on the other hand, consist of engraved and slipped vessel sherds from carinated bowls, some simple bowls, and bottles. The fine ware vessel sherds more frequently are smoothed or burnished on the exterior vessel surface, and as will be discussed in more detail below, the fine ware vessels from 4ILR35I were made, fired, and used in different ways than were the utility ware vessels.

The fine ware sherds from 41 LR351 include 13 rim and 47 body sherds that have engraved and/or red-slipped decorations (Table 3). More than $90 \%$ of the rim sherds are from engraved vessels, including carinated bowls and compound bowls. There are also body sherds representcd in the line wares from the site. In addition to the 21 red-slipped sherds that may be from plain slipped vessels (bottles and carinated bowls) as well as from the undecorated portions of slipped vessels, $30.8 \%$ of the engraved sherds are from vessels that have also been red-slipped (Table 3). Approximately 55\% of the fine ware sherds from 41LR35I have a red slip on either one or both vessel surfaces.

Table 3. Decorated fine ware sherds from 41LR351.

\begin{tabular}{llll}
\hline Decorative elements & Rim & Body & $\%$ RS \\
\hline Engraved & & & \\
parallel engraved lines & - & 8 & - \\
diagonal engraved lines & 3 & 3 & 16.7 \\
diagonal-horizontal engraved lines & 3 & 1 & 75.0 \\
vertical-diagonal engraved lines & 1 & - & - \\
opposed diagonal engraved lines & 1 & 1 & - \\
hatched engraved zone & - & 2 & - \\
cross-hatched engraved lines & 1 & 2 & 80.0 \\
horizontal engraved lines & 3 & 1 & - \\
int. horizontal engraved lines & - & 8 & 50.0 \\
single straight engraved line & - & 27 & 30.8 \\
Suhtotal & 12 & & 100.0 \\
Red-slipped & & & 100.0 \\
int./ext. red-slipped & & 13 & 100.0 \\
ext. red-slipped & 1 & 20 & 55.0 \\
\hline Subiotal & - & 47 & - \\
\hline Totals & 1 & & \\
\hline
\end{tabular}

RS=red-slipped 
The engraved sherds have simple geometric decorative elements composed of horizontal, parallel (wherc the sherd orientation is not known), diagonal, opposed diagonal, vertical-diagonal, zoned hatched, and cross-hatched lines (Figure 3a-c; see also Perttula 2010:Figures 1a-e and 2a-d and Table 2). The decorative elements are confined to the rim of carinated bowls, compound bowls, and probably simple bowls.
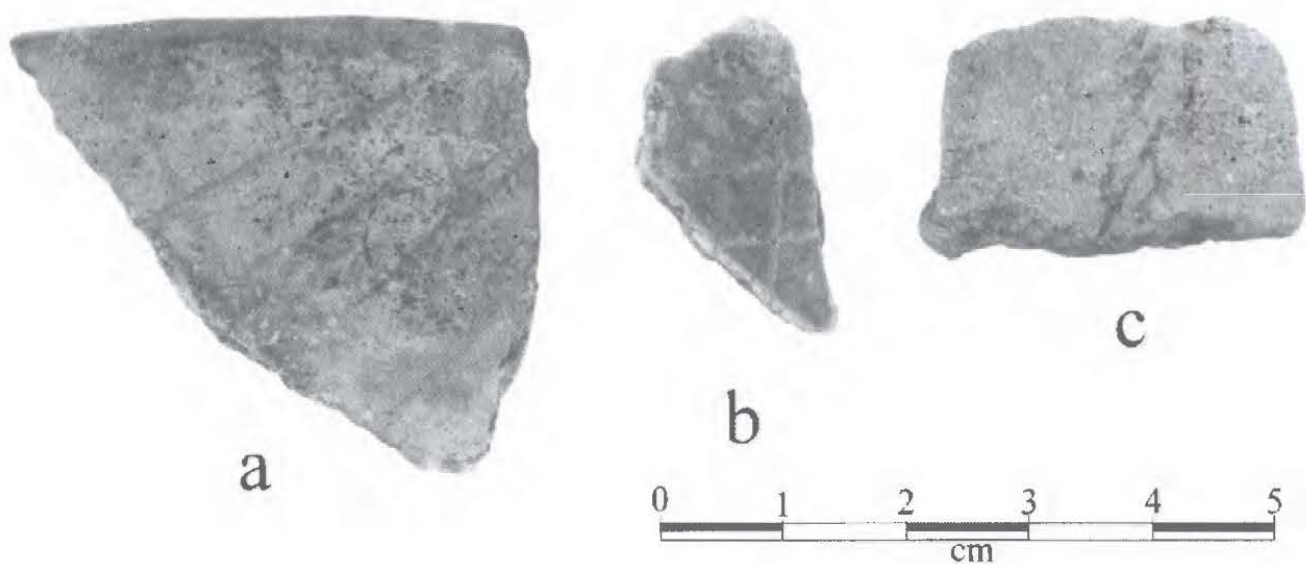

Figure 3. Selected engraved sherds from 41LR351: a, diagonal engraved rim; $b$, cross-hatched engraved body sherd; c, zone hatched body sherd.

Two sherds from 41LR351 compare favorably to decorative elements on Holly Fine Engraved vessels (see Suhm and Jelks 1962:Plates 39 and 40) in that they have closely spaced sets of vertical and diagonal engraved lines on a vessel rim (see Perttula 2010:Figures 1b-c and Figure 2a). Where they differ from classic examples of Holly Fine Engraved is in the absence of excised triangles (Suhm and Jelks 1962:77) as an integral attribute of the motif, as well as the fact that the engraved lines are finely executed. According to Story (2000), Holly Fine Engraved vessels were likely manufactured between ca. A.D. 850-1300 in various locales across Northeast Texas.

The other engraved sherds (see Perttula 2010:Figures 1a, d-e and 2b-d and Table 2), many of which are red-slipped, are likely from Sanders Engraved vessels (see Brown 1996:403-404 and Figures 2-38a, c, e and 2-39a-c, i, m; Krieger 1946:Plate 27, 2000:139, 142-143; Suhm and Jelks 1962:137 and Plate 69). Suhm and Jelks (1962:137) describe the decorative elements on Sanders Engraved vessels as "very simple straight-line motifs in a single zone around rims...the designs may consist only of parallel lines pitched in opposite directions at intervals...groups of vertical lines at intervals....and a continuous series of triangles filled with hachuring or crosshatching."

The red-slipped sherds comprise $35 \%$ of the fine wares from 41LR351. If these sherds are from vessels that are decorated only with red-slipping on either one or both vessel surfaces, then they can be classified as Sanders Plain (Suhm and Jelks 1962:139 and Plate 70; see also Krieger 1946:Plates 24-26). According to Brown (1996:401), Sanders Plain is "a grog tempered slipped and undecorated ceramic."

The majority of the decorated utility ware sherds from 4ILR351 have incised decorative elements (Table 4 and Figure 4a-f; see also Perttula 2010:Figures 3b, d, f and 4a-g). The incised sherds comprise $68 \%$ of the decorated utility wares, including $74 \%$ of the utility ware rim sherds. Other utility wares include rim and body sherds with various punctated elements $(15 \%)$, sherds with incised-punctated designs ( $7 \%$, see Perttula 2010:Figure $3 \mathrm{a}, \mathrm{c}, \mathrm{e})$, and one sherd $(1 \%)$ with a simple appliqued design. 
Table 4. Decorated utility ware sherds from 41LR351.

\begin{tabular}{|c|c|c|}
\hline Decorative elements & $\operatorname{Rim}$ & Body \\
\hline diagonal incised lines & 12 & 7 \\
\hline diagonal opposed incised lines & 3 & 6 \\
\hline opposed incised lines & 1 & - \\
\hline cross-hatched incised lines & 9 & 7 \\
\hline parallel incised lines & - & 21 \\
\hline vertical incised lines & 1 & 2 \\
\hline vertical-horizontal incised lines & - & 1 \\
\hline vertical-diagonal incised lines & 1 & - \\
\hline horizontal-diagonal incised lines & - & 1 \\
\hline straight incised line & - & 2 \\
\hline subtotal & 27 & 47 \\
\hline tool punctated rows & 2 & 2 \\
\hline tool punctates, free & 1 & - \\
\hline fingernail punctated rows & 2 & 1 \\
\hline cane punctated rows & 1 & 1 \\
\hline small circular tool punctated rows & - & 2 \\
\hline large circular punctated rows & 1 & - \\
\hline linear punctated rows & - & 1 \\
\hline free punctates & - & 1 \\
\hline subtotal & 7 & 8 \\
\hline parallel incised band with circular punctates & - & 1 \\
\hline parallel incised band with cane punctates & - & 2 \\
\hline vertical incised lines above circular punctates & - & 1 \\
\hline tool punctate-filled incised triangles & 2 & 3 \\
\hline subtotal & 2 & 7 \\
\hline curvilinear appliqued ridges & - & 1 \\
\hline Totals & 36 & 63 \\
\hline
\end{tabular}

The incised sherds (see Perttula 2010:Figures $3 \mathrm{~b}, \mathrm{~d}, \mathrm{f}$ and Figure $4 \mathrm{a}-\mathrm{g}$ ), and several of the incisedpunctated sherds (see Figure 5b), are likely from Canton Incised vessels that have "parallel diagonal lines around rim, all in the same direction... alternating in direction...alternating with intervening spaces filled with small punctations or fingernail marks...nested together in hachures...or crossed in a diagonal grid" (Suhm and Jelks 1962:23; see also Krieger 1946:Plate $28 f-g)$. At 41LR351, the most common decorative elements (based on 27 rim sherds) feature sets of diagonal incised or cross-hatched incised lines. The two rims with tool punctate-filled incised triangles (see Perttula 2010:Figure 3c, e and Figure 5a) are also from Canton Incised vessels.
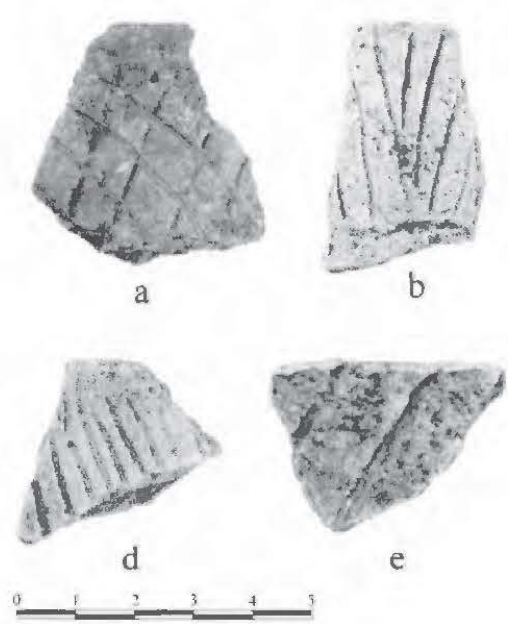

Figure 4. Incised rim sherds: a, cross-hatched; b-c, diagonal opposed incised lines; $d-f$, diagonal incised lines. 
There are three incised-punctated sherds from 41LR351 that may be from Pennington Punctated-Incised vessels (see Perttula 2010:Figures $3 \mathrm{a}$ and $5 \mathrm{~b}$ ). These have well-defined parallel incised bands filled with either circular or cane punctations (see Table 4).

Other utility ware vessel at 41LR351 may have had a punctated zone (or rows of punctations) around
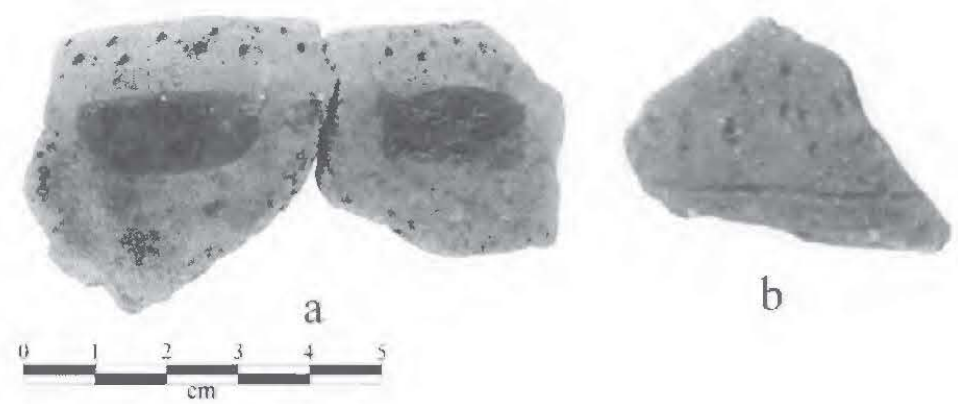

b

Figure 5. Incised-Punctated and Punctated sherds: a, punctated zone on carinated rim; $b$, zoned incised-punctated body sherd. the top of the vessel (i.e., along the rim of carinated bowls, see Figure 5a-b), or perhaps had punctations on both the rim and body. In these cases. the punctations were made with tools, fingernails, or a cut piece of cane (see Perttula 2010:Figure 6a-d; see Table 4). One body sherd has curvilinear appliqued ridges on it (see Perttula 2010:Figure 5c), perhaps part of a modeled element attached to the vessel surface.

\section{Plain Sherds}

The 823 plain sherds from 4ILR35I account for $80.5 \%$ of the ceramic assemblage. The plain sherds include 33 rim sherds ( $40.2 \%$ of all the rims), 736 body sherds ( $87 \%$ of all the body sherds), and 54 base sherds. There is also a single sherd from a loop handle (Figure 6a). One of the plain body sherds from Unit N100-E56 (30-40 cm bs) has a drilled hole ( $8.7 \mathrm{~mm}$ in diameter) (Figure $6 \mathrm{~b})$, suggesting it had been used as a spindle whorl in weaving activities at the site.

Based on the proportion of decorated $(n=49)$ and plain rims $(n=33)$, and the assumption that the number of rims is an accurate proxy for the relative frequency of vessels of different kinds, about $40 \%$ of the vessels at 41 LR351 are from plain, non-slipped vessels. At the Stallings site, by contrast, $89 \%$ of the rims are from plain, non-slipped vessels (Perttula 2008a).

\section{Discussion of the Ceramic Assemblage from 41LR351}

There are three distinct ceramic wares in the prehistoric Caddo sherd assemblage from 4ILR351: fine ware, utility ware, and plain ware. These three wares are not only different with respect to the kind of surface decorations found on them (see above), but also in terms of the technological analyses to be discussed below, including temper and paste, firing conditions, vessel wall thickness, surface treatment, and rim and lip form.
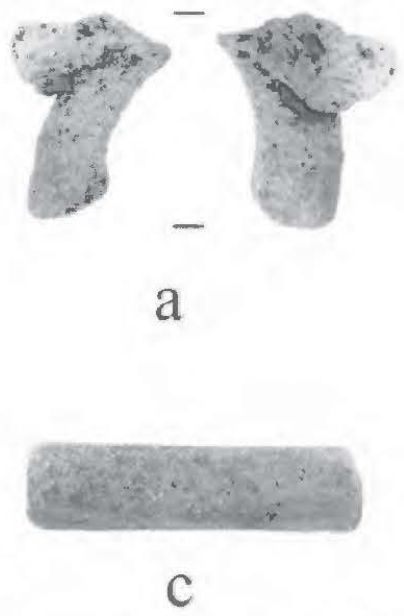

Figure 6. Other sherds from 41LR35I: a, loop handle sherd; $b$, spindle whorl; c, Red River pipe stem.

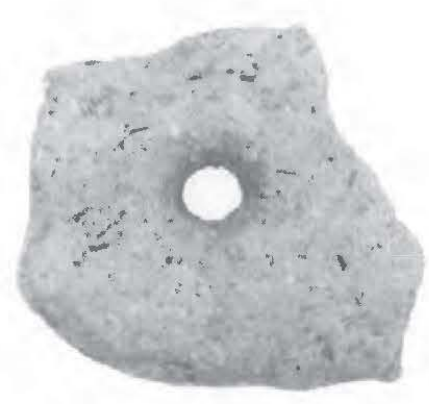

b

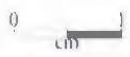




\section{Temper and Paste}

Between $95.5-100 \%$ of the fine ware, utility ware, and plain ware sherds from 41LR351 had grog (crushed sherds) added to the clay paste (Table 5). Crushed and burned bone and crushed hematite were also added to the paste as temper in all three wares. Bone occur in slightly higher but not statistically significant frequencies in the coarser utility wares as well as the plain wares, while hematite temper is particularly abundant in the utility wares. Sherds from vessels with a sandy paste (apparently from the infrequent use of a naturally sandy clay) are found in low frequencies $(6.0-6.5 \%)$ in all three wares (Table 5).

Table 5. Temper and paste categories by wares.

\begin{tabular}{|c|c|c|c|}
\hline Temper/paste category & Fine ware & Utility ware & Plain ware \\
\hline Grog & $67.7 *$ & 58.3 & 72.2 \\
\hline Grog/sandy paste & 3.2 & 2.1 & 4.5 \\
\hline Grog-organics & 9.7 & 4.2 & 1.5 \\
\hline Grog-organics/sandy paste & 3.2 & - & - \\
\hline Grog-bone & 9.7 & 12.5 & 11.3 \\
\hline Grog-bonc-hematite & 3.2 & 4.2 & 0.8 \\
\hline Grog-hematite & 3.2 & 10.4 & 4.5 \\
\hline Grog-hematite/sandy paste & - & 4.2 & 0.8 \\
\hline Bone & - & 2.1 & 3.0 \\
\hline Bone-organics & - & 2.1 & 0.8 \\
\hline Bone-hematite/sandy paste & - & - & 0.8 \\
\hline \multicolumn{4}{|l|}{ Summary: } \\
\hline sherds with grog & 100.0 & 95.8 & 95.5 \\
\hline sherds with bone & 12.9 & 20.8 & 16.5 \\
\hline sherds with hematite & 6.5 & 18.8 & 6.8 \\
\hline sherds with organics & 12.9 & 6.3 & 2.3 \\
\hline sherds with sandy paste & 6.5 & 6.3 & 6.0 \\
\hline Total Sample & 31 & 48 & 133 \\
\hline
\end{tabular}

*percentage; columns underlined and in bold represent significantly distinct proportions of temper-paste categories

The potters that lived at 41LR351 used bone and hematite temper for several reasons. In addition to it likely being a matter of personal preference or part of a family stylistic tradition for particular Caddo potters in vessel manufacture, the addition of coarse fragments of crushed bone and hematite would have made the clay more plastic and increased its strength and use-life, properties that were important in the successful manufacture of durable pottery vessels. Grog, on the other hand. contributes to the ability of the fired vessel to withstand heat-related stresses, as well as increasing its flexural strength. Such vessels would also have had better thermal conductivity (O'Brien et al. 1994:281; Rice 1987:362). These attributes suggest that the grog-tenipered wares from 41LR3.3I were intended for long and common use, both for the cooking of food stuffs but also for serving hot and cold foods.

There are differences in the proportion of fine ware and utility ware sherds with either bonc (33.3-37.7\%) or hematite (3.7-4.9\%) temper from the earlier Stallings site ceramic assemblage (Perttula 2008a:Table 4) and 
the later ceramic assemblage at 4ILR351. The use of bone temper seemingly decreased over time - to only $12.9-20.8 \%$ at $41 \mathrm{LR} 351$ - while hematite was more frequently selected as a tempering agent $(6.5-18.8 \%)$.

\section{Firing Conditions}

The Caddo fine ware and utility vessel sherds, as well as the plain ware sherds, from 41LR351, were fired primarily in a rcducing or low oxygen environment, probably smothering the vessel in a bed of coals from a wood fire (Table 6). This method of firing is typical of Caddo ceramic assemblages throughout East Texas, almost without exception. The percentage of fine ware sherds fired in a reducing environment is $90.2 \%$, compared to $73.0 \%$ for the utility wares, and $66.1 \%$ for the plain rims (see below).

Table 6. Firing conditions.

\begin{tabular}{llll}
\hline Firing category & Fine ware & Utility ware & Plain ware \\
\hline A (Oxidizing) & - & $16.7^{*}$ & $\underline{\mathbf{1 8 . 0}}$ \\
B (Reducing) & $\underline{\mathbf{4 1 . 9}}$ & 16.7 & 7.5 \\
C & 3.2 & 4.2 & 5.3 \\
D (Incompletely & - & 2.1 & 0.8 \\
E Oxidized) & - & 2.1 & 5.3 \\
F & 29.0 & 31.3 & 31.6 \\
G (Reducing, cooled & 16.1 & 16.7 & $\underline{\mathbf{2 2 . 5}}$ \\
H in open air) & 3.2 & $\underline{\mathbf{3}}$ & 4.5 \\
K (Sooted, smudged, & - & 2.1 & 2.3 \\
L refired/crratic & 3.2 & - & 0.8 \\
X firing) & 3.2 & - & 1.5
\end{tabular}

Summary

\begin{tabular}{llll} 
Oxidized firing & 0.0 & 16.7 & $\mathbf{1 8 . 0}$ \\
$\begin{array}{l}\text { Reduced firing } \\
\text { Incompletely oxidized } \\
\text { firing }\end{array}$ & $\mathbf{4 1 . 9}$ & 16.7 & 7.5 \\
$\begin{array}{l}\text { Reduced firing, open } \\
\text { air cooling }\end{array}$ & 3.2 & 8.4 & 11.4 \\
$\begin{array}{l}\text { Sooted, smudged, } \\
\text { refired/erratic firing }\end{array}$ & 48.3 & 56.3 & $\underline{\mathbf{5 8 . 6}}$ \\
\hline Totals & $\mathbf{6 . 4}$ & 2.1 & 4.6 \\
\hline
\end{tabular}

*percentage; columns underlined and in bold represent significantly distinct proportions of temper-paste eategories

After firing, most of the vessels made and used at 41 LR351 were apparently cooled in a high oxygen environment (48.3-58.6\%, see Table 6), meaning that the fire-hardened vessels were probably removed from the fire to cool, producing a thin oxidized or lighter surface on either one or both vessel surface. The consistency in how the vessels at the site were fired indicates rather clearly that the prehistoric Caddo potters who made those vessels were well-versed in regulating firing and cooling temperatures as well as maintaining 
control over the final finished end product, namely the manufacture of durable and relatively hard vessels with certain colors and hues.

A few sherds in the three wares (2.1-6.4\%) have distinctive fired cores. These were either fired in an oxidizing environment, then reduced, leaving a thin black smudged or sooted band along the vessel interior (firing conditions K and L, Perttula 2005:Figure 5-30k-l). Other sherds-including fine wares and plain wares - have multiple thin bands of reduced and oxidized clay in the vessel core (firing condition $\mathrm{X}$ ).

\section{Thickness of the Ceramic Wares}

The fine ware vessel sherds from 4lLR351 are thinner than the decorated utility ware or plain ware sherds, particularly along the body, but the rim walls are also thinner on the fine wares than they are on the decoratcd utility wares or plain wares (Table 7). For the rims, fine ware vessels are less than $10 \%$ thinnerwalled than either the utility wares or the plain ware vessel rims. Body sherds are about $20 \%$ thinner in the fine wares compared to either the utility or plain wares.

Table 7. Thickness of the ceramic wares.

\begin{tabular}{llll}
\hline Sherd type & $\begin{array}{l}\text { Fine ware } \\
(\mathrm{mm})\end{array}$ & $\begin{array}{l}\text { Utility ware } \\
(\mathrm{mm})\end{array}$ & $\begin{array}{l}\text { Plain ware } \\
(\mathrm{mm})\end{array}$ \\
\hline Rim & $\begin{array}{l}6.56 \pm 0.47 \\
\text { range, } 5.8-7.9\end{array}$ & $\begin{array}{l}7.00 \pm 1.16 \\
\text { range, } 4.9-10.0\end{array}$ & $\begin{array}{l}6.74 \pm 0.66 \\
\text { range. } 5.9-8.8\end{array}$ \\
& $\begin{array}{l}6.16 \pm 0.87 \\
\text { range, } 4.5-8.8\end{array}$ & $\begin{array}{l}7.24 \pm 1.00 \\
\text { range, } 4.2-9.2\end{array}$ & $\begin{array}{l}7.39 \pm 0.82 \\
\text { range, } 4.3-9.6\end{array}$ \\
Body & - & - & $10.79 \pm 0.88$ \\
\hline
\end{tabular}

These variations in vessel wall thickness are likely related to functional and technological differences in how these different wares were intended to be used by Caddo potters. The more substantial vessel walls in the utility wares and plain wares would be well suited to the cooking and heating of foods and liquids and would have contributed to their ability to withstand heat-related stresses. Fine wares were probably intended for use in the serving of foods and liquids.

Another factor that would influence vessel body wall thickness would be the sequence in which a vessel was constructed (Krause 2007:35). Vessels constructed from the bottom up, as these prehistoric Caddo dccorated vessels likely were, would tend to have thinner walls moving up the vessel body toward aie rim, with the lower portion of the vessel-especially on the base-usually significantly thicker than the upper portions of the vessel.

\section{Surface Treatment}

Fine ware vessel sherds at 4ILR35I are more frequently smoothed and/or burnished than the utility wares or plain wares (Table 8 ), particularly on exterior vessel surfaces. When not burnished, the fine wares tend to be well smoothed on the vessel exterior; it is suspected that most of the fine wares at the site were actually burnished after they were fired, but the burnish has been degraded by time and soil conditions. 
Table 8. Surface treatment by ceranic ware.

\begin{tabular}{llll}
\hline Surface treatment & Fine ware & Utility ware & Plain ware \\
\hline Interior smoothed & $\mathbf{4 8 . 4 ^ { * }}$ & 27.1 & 15.8 \\
Exterior smoothed & $\mathbf{4 8 . 4}$ & 10.4 & 28.6 \\
Exterior burnished & $\mathbf{6 . 5}$ & - & - \\
Interior burnished & - & - & 0.8 \\
\hline Totals & 31 & 48 & 133 \\
\hline
\end{tabular}

*percentage; columns underlined and in bold represent significantly distinct proportions of temper-paste categories

Utility ware and plain ware sherds are from vessels that are conmonly smoothed on one or both vessel surfaces (see Tablc 8), with utility ware vessels more likely smoothed on the interior surface, but more frequently smoothed on the exterior surface of plain wares (probably from bowls or the lower and undecorated portion of carinated bowls). The frequency of utility ware vessels that have been smothed on exterior surfaces ( $10.4 \%)$ suggests that not only were decorations on these vessels most likely restricted to rim or upper vessel arcas (and left unsmoothed), but that the undecorated or lower portions of these vessels were sometimes smoothed before or after firing lor some purpose.

The smoothing of utility ware interior vessel surfaces (27.1\%) was probably done to lower the permeability and increase the heating effectiveness of particular vessels in cooking tasks (cf. Rice 1996: I48). With the fine wares, the well-smoothed and/or burnished interior surfaces may have been advantageous in the repeated use of these wares as food serving vessels. The purpose of exterior smoothing and burnishing (which are more common surface treatments in the fine wares) may have been for stylistic and display purposes, creating a flat and lustrous surfacc wcll-suited to highlight the engraved and/or slipped exterior surfaces of the fine ware vessels.

\section{Rim and Lip Form}

They are several rim and lip forms in the fine ware, utility ware, and plain ware rim sherds (Table 9 and Figure 7a-c), suggesting they come from different sorts of vessels of wide-ranging sizes, although the rim sherds are in most cases too small to accurately determine the form of the vessel. Most appear to be from bowls and jars, as well as carinatcd bowls and bottles. Wherc measurable, vessel urifice diameters ranged from at least $12.0 \mathrm{~cm}$ to as large as $27.0 \mathrm{~cm}$ in size.

Table 9. Rim and lip form.

\begin{tabular}{llll}
\hline Rim and Lip Forms & Fine ware & Utility ware & Plain ware \\
\hline Direct-Rounded & $\mathbf{3 8 . 5 ^ { * }}$ & 44.1 & $\mathbf{6 7 . 7}$ \\
Direct-Rounded, ext. folded & $\mathbf{3 8 . 5}$ & 8.8 & 9.7 \\
Direct-Rounded, collared rim & - & 2.9 & - \\
Direct-Flat & 15.4 & $\mathbf{3 2 . 4}$ & 9.7 \\
Direct-Flat, ext, folded & - & - & -7 \\
Everted-Rounded & 7.7 & 8.9 & 3.2 \\
--Rounded & - & 34 & 31 \\
Totals & 13 & & \\
\hline
\end{tabular}

*percentage; columns underlined and in bold represent significantly distinct proportions of temper-paste categories 


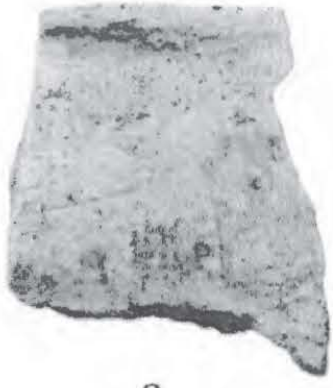

a
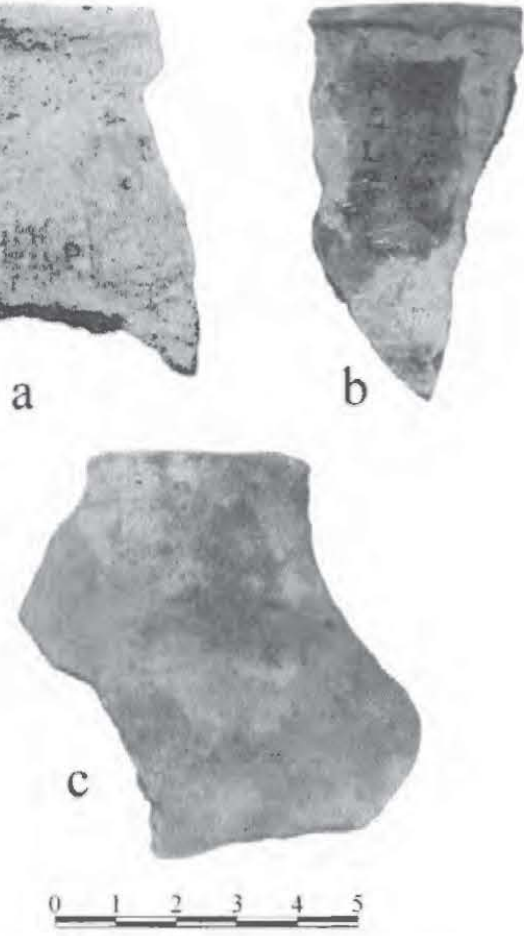

Figure 7. Selected plain rims from 4ILR35I.

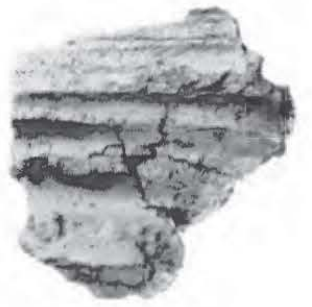

a

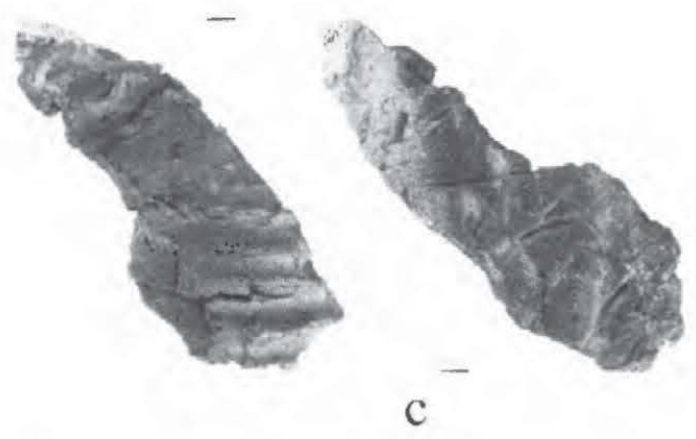

Where rim and lip form could be determined, more than $92 \%$ of the rims have a direct or vertical rim profile (see Table 9). One rim from a fine ware vessel has an everted profile and is probably from a compound bowl with an everted upper rim panel. Most of the vessels in turn have a rounded lip (especially the plain wares), with the remainder having flat lips (especially the utility wares). Several other rims in all three wares have a different and distinct lip treatment, where the lip has been folded over to the exterior surface. This form of lip treatment is present in $38.5 \%$ of the fine ware rims, $8.8 \%$ of the utility ware rims, and $19.4 \%$ of the plain ware rims (see Table 9).

\section{Red River Pipe Sherd}

A small portion of a Red River long-stemmed pipe was recovered from N98 E55, 50-60 cm bs (see Figure $6 \mathrm{c}$ ). It has a finely crushed bone temper and a smoothed exterior surface. The exterior diameter of the stem sherd is $7.7 \mathrm{~mm}$, suggesting it is from a ca. A.D. 1000-1200 Miller's Crossing variety of Red River pipe (see Hoffman 1967)

\section{Daub}

Substantial amounts of daub were recovered in the excavations at 4ILR351 (Gary Sykes, 2012 personal communication). The samples examined had impressions of sticks ( $7-8 \mathrm{~mm}$ in width), twigs, grass, and cane (Figure 8). The daub pieces ranged from $15-30 \mathrm{~mm}$ in thickness, indicating a substantial clay layer was added to the walls of houses at the site. Most of the daub was blackened on both sides, suggesting that the daub was smothered while it was baking, probably by sediments deposited on the burning structure.

\section{Burned Clay}

There are also seven pieces of burned clay in the ceramic assemblage from 41LR351 (Table 10). These pieces are likely the fragmentary evidence of the use of clay hearths or earth ovens during the Caddo occupation.

Figure 8. Daub from N99 E56 at 41LR351. 
Table 10. Burned clay from 41LR351.

\begin{tabular}{lllc}
\hline Lot No. & Provenience & Level & No. of burned clay pieces \\
\hline 110 & N99 E58 & Unknown & 1 \\
130 & N98 E54 & lv. 4 & 2 \\
137 & N98 E54 & lv. 6 & 3 \\
150 & N99 E54 & lv. 5 & 1 \\
\hline
\end{tabular}

\section{Chipped Stone Artifacts}

The chipped stone artifacts from 41LR351 include arrow points and arrow point preforms $(n=10)$, dart points $(n=41)$, an assortment of bifaces and flake tools $(n=51)$, hammerstones $(n=2)$, cores $(n=4)$, and pieces of lithic debris $(\mathrm{n}=2036)$. These tools can be associated by style, technology, and depth to either prehistoric Caddo, Woodland, or late Archaic occupations at the site.

\section{Arrow Points}

The arrow points from 4lLR351 are found predominantly between $0-50 \mathrm{~cm}$ bs (Figure 9). They include five Homan points, one Alba point, one Morris point, a preform, and two tip/blade fragments (Table 11 and Figure 10a-g).

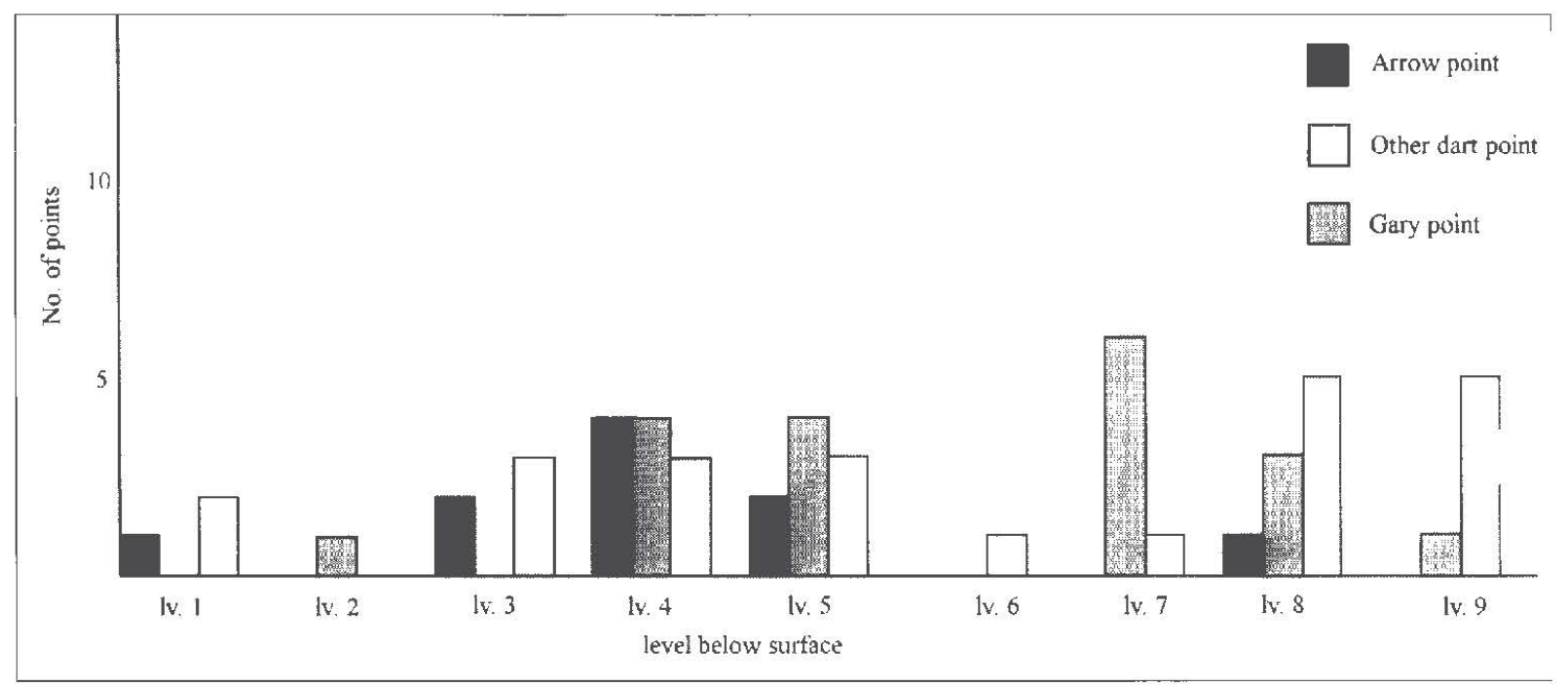

Figure 9. Vertical provenience of arrow points, Gary dart points, and other dart points trom 4ILR351. 
Table 11. Arrow points from 41LR351.

\begin{tabular}{|c|c|c|c|c|c|c|c|}
\hline $\begin{array}{l}\text { Provenience } \\
\text { (Unit and } \mathrm{cm} \mathrm{bs} \text { ) }\end{array}$ & Type & Raw Material & $\begin{array}{c}\mathrm{L} \\
(\mathrm{mm})\end{array}$ & $\begin{array}{c}\mathrm{W} \\
(\mathrm{mm})\end{array}$ & $\begin{array}{l}\mathrm{TH} \\
(\mathrm{mm})\end{array}$ & $\begin{array}{l}\text { SW } \\
(\mathrm{mm})\end{array}$ & FL \\
\hline N98 E55, 0-10 & Homan & $\begin{array}{l}\text { Big Fork } \\
\text { green chert }\end{array}$ & 27.8 & 11.5 & 3.0 & 5.4 & uni. \\
\hline N99 E54, 20-30 & Homan & white NOV. & 16.0 & 9.5 & 3.6 & 4.5 & bif. \\
\hline N100 E56, 20-30 & Homan & $\begin{array}{l}\text { Big Fork } \\
\text { chert }\end{array}$ & 22.1 & 12.9 & 3.9 & 5.9 & bif. \\
\hline N95 E55, 30-40 & tip/blade & $\begin{array}{l}\text { Big Fork } \\
\text { chert }\end{array}$ & - & 15.1 & 3.1 & - & uni. \\
\hline N97 E60, 30-40 & preform & black chert & 23.3 & 16.1 & 2.3 & - & uni. \\
\hline N98 E54, 30-40 & Homan & $\begin{array}{l}\text { Big Fork } \\
\text { chert }\end{array}$ & $23.0+$ & 13.0 & 3.2 & 4.5 & uni. \\
\hline N98 E55, 30-40 & Alba & gray chert & 29.0 & 15.9 & 2.8 & 6.2 & uni. \\
\hline N98 E59, 40-50 & $\begin{array}{l}\text { tip/blade } \\
\text { frag. }\end{array}$ & $\begin{array}{l}\text { dark gray } \\
\text { chert }\end{array}$ & - & - & 3.6 & - & bif. \\
\hline N99 E54, 40-50 & Homan & red jasper & 21.4 & 10.8 & 2.3 & 5.2 & uni. \\
\hline N97 E55, 70-80 & Morris & black chert & 24.0 & 13.3 & 3.9 & 6.6 & uni. \\
\hline
\end{tabular}

$\mathrm{L}=$ =ength; $\mathrm{W}=$ width; $\mathrm{TH}=$ thickness; $\mathrm{SW}=$ stem width; $\mathrm{FL}=$ flaking; uni.=unifacial; bif.=bifacial; $\mathrm{NOV=novaculite}$

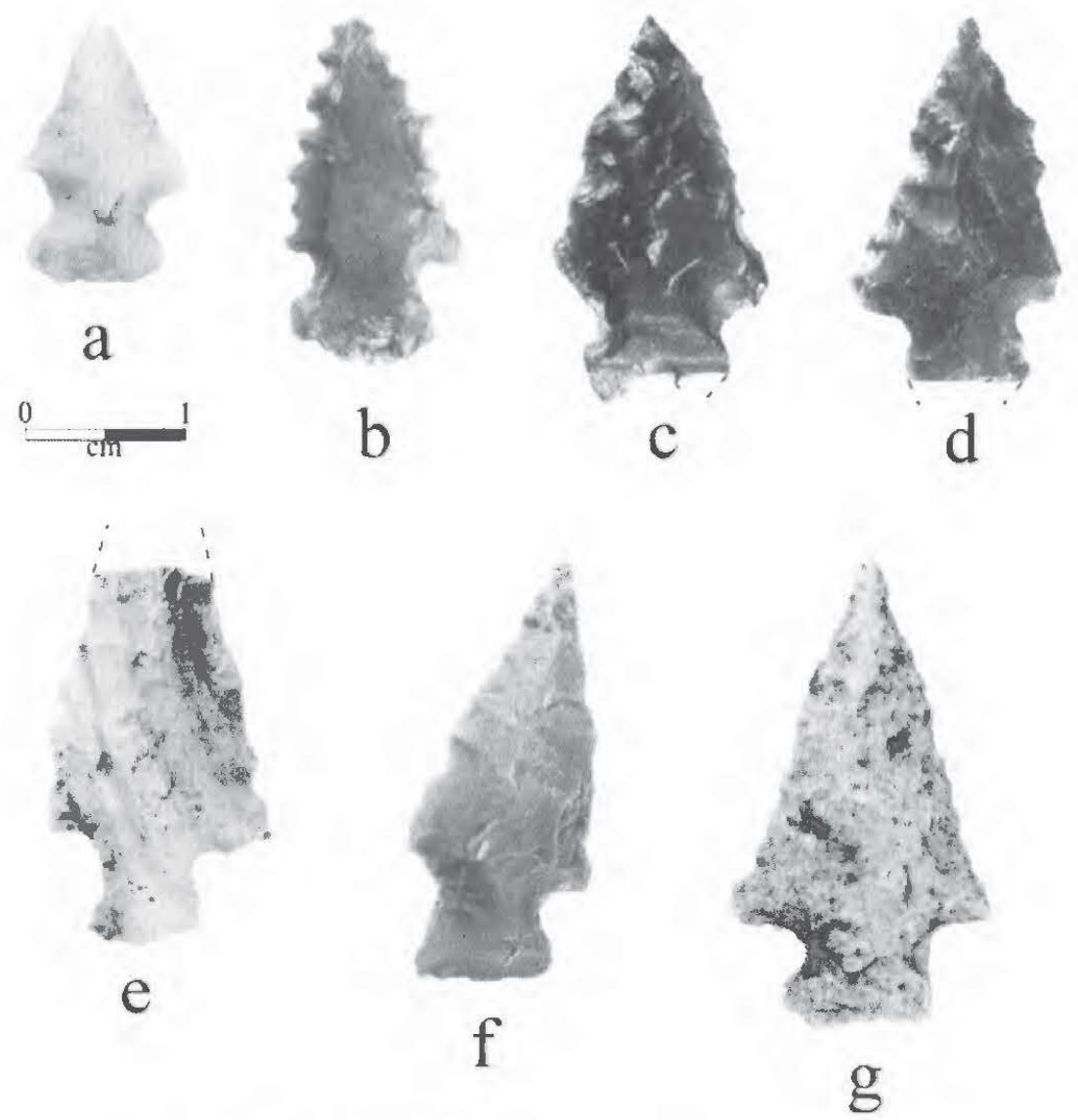

Figure 10. Arrow points from 41LR351: a-b, e-f, Homan; c, Morris; g,Alba. 
The arrow point styles (Alba and Homan) are consistent with an Early Caddo occupation at 41LR351, although the Morris point has been suggested to have been made and used in both Early and Middle Caddo periods (Duncan et al. 2007:88). The arrow points in the assemblage are uniformly made from Red River gravels that contain a variety of Ouachita Mountains cherts and novaculite, as well as jasper. Most of the arrow points are only unifacially flaked to shape, but two of the Homan arrow points are bifacially knapped.

\section{Dart Points}

The dart points from 41LR351 are dominated by contracting stem Gary points (Table 12), as they comprise $51.2 \%$ of the dart point sample from the site. Other identified dart point types in the assemblage include Edgewood $(n=2)$, Bulverde $(n=2)$, Godley $(n=1)$, cf. Wells $(n=1)$, and cf. Morrill $(n=1)$.

Table 12. Gary dart points from 41LR351.

\begin{tabular}{|c|c|c|c|c|c|c|c|}
\hline $\begin{array}{l}\text { Provenience } \\
\text { (Unit and } \mathrm{cm} \mathrm{bs} \text { ) }\end{array}$ & Raw Material & $\begin{array}{c}\mathrm{L} \\
(\mathrm{mm})\end{array}$ & $\begin{array}{c}\mathrm{W} \\
(\mathrm{mm})\end{array}$ & $\begin{array}{l}\mathrm{TH} \\
(\mathrm{mm})\end{array}$ & $\begin{array}{l}\mathrm{SW} \\
(\mathrm{mm})\end{array}$ & FL & RS \\
\hline N98 E55, 10-20 & gray-yellow NOV & 43.1 & 25.3 & 6.5 & 15.0 & uni. & + \\
\hline N97 E55, 30-40 & brown jasper & 35.6 & 15.0 & 6.2 & 11.8 & uni. & + \\
\hline N99 E55, 30-40 & black chert & $41.0+$ & 24.9 & 7.1 & 17.0 & bif. & + \\
\hline N99 E56, 30-40 & quartzite & 33.0 & 26.0 & 6.2 & 13.1 & bif. & + \\
\hline N100 E56, 30-40 & red jasper & $43.2+$ & 38.0 & 8.7 & 20.9 & bif. & + \\
\hline N98 E55, 40-50 & $\begin{array}{l}\text { brown-dark brown } \\
\text { chert }\end{array}$ & 60.0 & 36.0 & 12.2 & 24.0 & bif. & + \\
\hline N99 E54, 40-50 & brown chert & $34.0+$ & 23.9 & 8.0 & 17.1 & bif. & + \\
\hline N100 E51, 40-50 & brown jasper & 49.0 & 35.0 & 5.9 & 22.1 & uni. & + \\
\hline N100 E56, 40-50 & brown chert & 33.9 & 13.8 & 5.7 & 13.2 & bif. & + \\
\hline N95 E55, 60-70 & black chert & $43.0+$ & 37.2 & 9.3 & 21.2 & bif. & + \\
\hline N98 E54, 60-70 & quartzite & 43.2 & 28.4 & 7.0 & 19.8 & bif. & + \\
\hline N99 E58, 60-70 & petrified wood & 27.0 & 20.1 & 7.4 & 14.2 & bif. & + \\
\hline N99 E58, 60-70 & quartzite & 57.9 & 25.2 & 10.2 & 17.0 & bif. & + \\
\hline N101 E53, 60-70 & quartzite & 33.0 & 42.9 & 8.9 & 20.0 & bif. & + \\
\hline N101 E53, 60-70 & quartzite & 43.2 & 27.0 & 5.1 & 13.4 & bif. & + \\
\hline N95 E55, 70-80 & brown jasper & - & 20.5 & 6.0 & 14.0 & bif. & + \\
\hline N96 E55, 70-80 & black chert & - & - & - & 20.0 & bif. & - \\
\hline N100 E51, 70-80 & grayish-brown chert & - & 24.9 & 6.2 & 17.0 & bif. & - \\
\hline N100 E51, 70-80 & brown jasper & 39.0 & 18.9 & 4.2 & 13.2 & bif. & + \\
\hline N95 E55, 80-90 & quartzite & - & - & - & - & bif. & - \\
\hline N101 E53, 80-90 & quartzite & 33.2 & 22.1 & 6.2 & 13.0 & uni. & + \\
\hline
\end{tabular}

$\mathrm{L}=$ length; $\mathrm{W}=$ width; $\mathrm{TH}=$ thickness; $\mathrm{SW}=$ stem width; $\mathrm{FL}=$ flaking; $\mathrm{RS}=$ resharpened $++=$ present; NOV $=$ Novaculite

The Gary dart points occur throughout the archaeological deposits at 4lLR351, from 10-90 $\mathrm{cm}$ bs (see Table 12 and Figure 9), but they are concentrated between $30-50 \mathrm{~cm}$ bs (38\%) and $60-80 \mathrm{~cm}$ bs (48\%). The majority of the Gary points have resharpened blades and are bifacially flaked (Figure 11a-j), but are diverse with respect to their overall size (especially thickness and stem width) and use of lithic raw materials. Six of the Gary points found between $30-80 \mathrm{~cm}$ bs have a cortical remnant on the stem, indicating they were made from flakes, and are not the product of direct pebble reduction. 


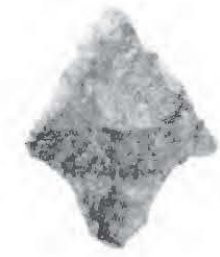

a

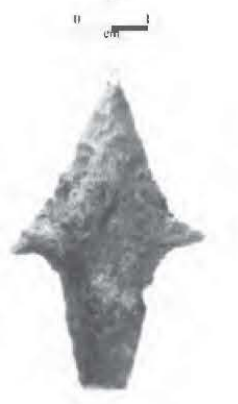

$\mathrm{e}$

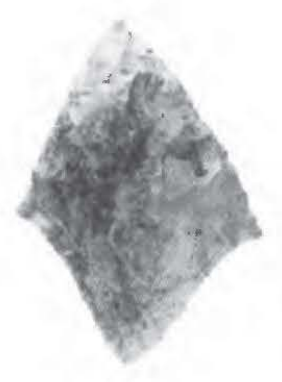

$\mathrm{h}$

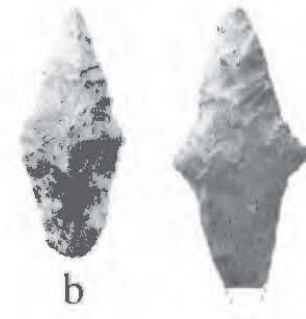

c

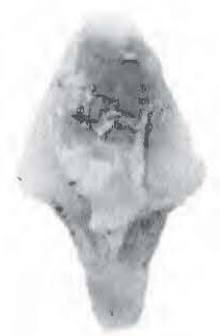

f

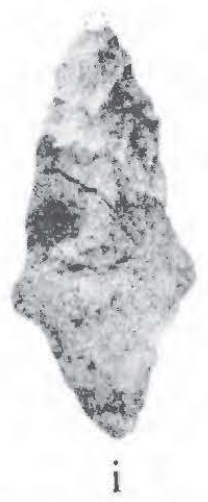

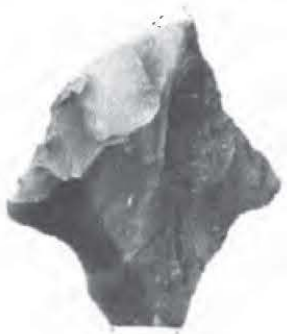

g

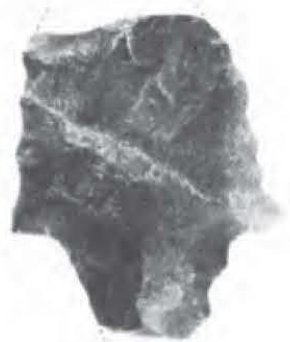

j

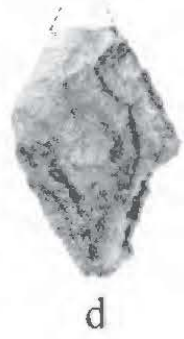

Figure 11. Gary dart points from 41LR351.

Based on Schambach's (1982:Tables 7-2 to 7-4) definition of Gary point varieties and various measurements of point size, there are four Gary, var. Gary points, four Gary, var. LeFlore points, and 11 Gary, var. Camden points in the 41LR351 assemblage. This in turn indicates that the main accumulation of Gary points at the site took place after ca. A.D. 200 (see Schambach 1982:176), but that the site was also occupied in the early part of the Woodland period (ca. 500 B.C.-A.D. 200).

The Gary points are manufactured from a variety of lithic raw materials, either obtained in local upland or interfluvial gravel sources or were procured in Red River gravels not far to the north of the site. The most common raw materials used include quartzite $(33 \%)$, red and brown jasper (24\%), and black Big Fork chert $(14 \%)$; the quartzite was likely obtained in local gravels, while the jasper and Big Fork chert are from Red River gravels (cf. Dowd 2011). Other local raw materials that were used include petrified wood and brown chert, comprising $14 \%$ of the Gary points, while the remainder $(14 \%)$-novaculite and various other cherts-are Ouachita Mountains materials from Red River gravels.

The other dart points from 4ILR351 include tip fragments ( $n=3$ ), tip/blade fragments $(n=4)$, preforms $(n=2)$, stem and stem/blade fragments $(n=3)$, unidentifiable points $(n=1)$, and seven points that can be identified with (Table 13), or compared favorably with, defined dart point types (see Turner et al. 2011). The other dart points are found between $0-10 \mathrm{~cm}$ bs and $80-90 \mathrm{~cm}$ bs, but are concentrated in the lowest depths of the archaeological deposits (see Figure 9).

Table 13. Other dart points from 41LR351.

\begin{tabular}{|c|c|c|c|c|c|c|c|}
\hline $\begin{array}{l}\text { Provenience } \\
\text { (Unit and } \mathrm{cm} \text { bs) }\end{array}$ & Type & Raw Material & $\underset{(\mathrm{mm})}{\mathrm{L}}$ & $\begin{array}{c}\mathrm{W} \\
(\mathrm{mm})\end{array}$ & $\begin{array}{c}\mathrm{TH} \\
(\mathrm{mm})\end{array}$ & $\begin{array}{l}\mathrm{SW} \\
(\mathrm{mm})\end{array}$ & $\begin{array}{l}\text { FL/ } \\
\text { RS }\end{array}$ \\
\hline N99 E54, 0-10 & $\begin{array}{l}\text { expanding } \\
\text { stem, flat base }\end{array}$ & gray NOV & - & - & 4.9 & - & uni. \\
\hline N99 E54, 20-30 & cf. Wells & quartzite & - & - & - & 19.6 & bif. \\
\hline N100 E56, 20-30 & tip & quartzite & - & - & - & - & bif. \\
\hline N101 E53, 20-30 & tip & $\begin{array}{l}\text { reddish-gray } \\
\text { chert }\end{array}$ & - & - & - & - & bif. \\
\hline N96 E55, 30-40 & tip & brown jasper & - & - & - & - & bif. \\
\hline N99 E54, 30-40 & preform & quartzite & 53.3 & 24.0 & 12.0 & 22.2 & bif. \\
\hline
\end{tabular}


Table 13., cont.

\begin{tabular}{|c|c|c|c|c|c|c|c|}
\hline $\begin{array}{l}\text { Provenience } \\
\text { (Unit and } \mathrm{cm} \mathrm{bs} \text { ) }\end{array}$ & Type & Raw Material & $\begin{array}{c}\mathrm{L} \\
(\mathrm{mm})\end{array}$ & $\begin{array}{c}\mathrm{W} \\
(\mathrm{mm})\end{array}$ & $\begin{array}{l}\text { TH } \\
(\mathrm{mm})\end{array}$ & $\begin{array}{l}\mathrm{SW} \\
(\mathrm{mm})\end{array}$ & $\begin{array}{l}\text { FL/ } \\
\text { RS }\end{array}$ \\
\hline N99 E55, 30-40 & stem frag. & dark brown chert & - & - & 6.5 & - & bif. \\
\hline N95 E55, 40-50 & tip/blade & brown chert & - & - & - & - & bif. \\
\hline N98 E54, 40-50 & $\begin{array}{l}\text { tip/blade } \\
\text { chert }\end{array}$ & reddish-brown & - & - & - & - & bif. \\
\hline N101 E53, 40-50 & Edgewood & $\begin{array}{l}\text { grayish-brown } \\
\text { chert }\end{array}$ & 32.0 & 22.9 & 5.7 & 13.0 & bif./RS \\
\hline N99 E55, 50-60 & tip/blade & $\begin{array}{l}\text { very dark } \\
\text { gray chert }\end{array}$ & - & - & - & - & bif. \\
\hline N98 E54, 60-70 & Edgewood & gray chert & $26.0+$ & 20.5 & 5.2 & 14.6 & bif. \\
\hline N99 E58, 70-80 & Bulverde & orange NOV & 40.5 & 27.4 & 8.3 & 15.0 & bif. \\
\hline N100 E51, 70-80 & Godley & quartzite & 31.0 & 20.0 & 7.7 & 13.0 & bif. \\
\hline N100 E51, 70-80 & stem/blade & quartzite & - & - & - & - & bif. \\
\hline N100 E51, 70-80 & $\begin{array}{l}\text { rounded } \\
\text { stem }\end{array}$ & $\begin{array}{l}\text { dark gray } \\
\text { chert }\end{array}$ & - & - & - & - & uni. \\
\hline N95 E55, 80-90 & preform & gray chert & - & - & 7.9 & - & bif. \\
\hline N96 E55, 80-90 & tip/blade & black chert & - & - & - & - & bif. \\
\hline N99 E58, 80-90 & Bulverde & white chert & - & - & 4.5 & - & uni. \\
\hline N101 E53, 80-90 & cf. Morrill & quartzite & $38.0+$ & -24.2 & 7.9 & 12.0 & bif. \\
\hline
\end{tabular}

$\mathrm{L}=$ length $; \mathrm{W}=$ width $; \mathrm{TH}=$ thickness $\mathrm{SW}=$ stem width $; \mathrm{FL}=$ flaking; $\mathrm{RS}=$ resharpened bif.=bifacial; uni $=$ unifacial; $\mathrm{NOV}=$ Novaculite

The defined types are indicative of occasional use of the site in Late Archaic (Bulverde and Morrill, Figure 12e-f) and Woodland period (Godley and Edgewood, Figure 12b-d) times. Turner et al. (2011:170) suggest that Wells points date to the Middle Archaic period, from ca. 4000-2500 B.C., although their chronological affiliations in Northeast Texas have not been well established. The Wells point from 41LR351 has also not been ground along the stem, one of the distinguishing attributes of the type according to Turner et al. (2011:170).

The other dart points from 4ILR35I are also made from a variety of lithic raw materials, including quartzite $(30 \%)$, novaculite $(10 \%)$, and gray chert $(10 \%)$. As a group, higher quality knappable raw materials were preferred for the manufacture of these dart points, as 50\% are on Ouachita Mountains/Red River gravel cherts, $10 \%$ are novaculite, and $5 \%$ are on jasper. These materials comprise $65 \%$ of the other dart points, compared to $52 \%$ in the Gary dart point assemblage.

\section{Other Chipped Stone Tools}

There are eight biface or biface preform fragments in the chipped stone tools from 41LR351 (N98 E54, 20-30 cm bs; N99 E58, 60-70 cm bs and 70-80 cm bs; N99 E54, 60-70 cm bs; N95 E55, 70-80 cm bs; and N97 E55, 20-30 cm and 70-80 cm bs [two bifaces]). Seventy-five percent of the biface fragments are from the deeper archaeological deposits at the site, i.e., $60-80 \mathrm{~cm}$ bs. They range in thickness from $5.9-15.7 \mathrm{~mm}$, and represent initially shaped bifaces that were broken during manufacture before they could be well thinned and final shaped (for dart point production). They are made from brown jasper $(n=2)$, dark grayish-brown 


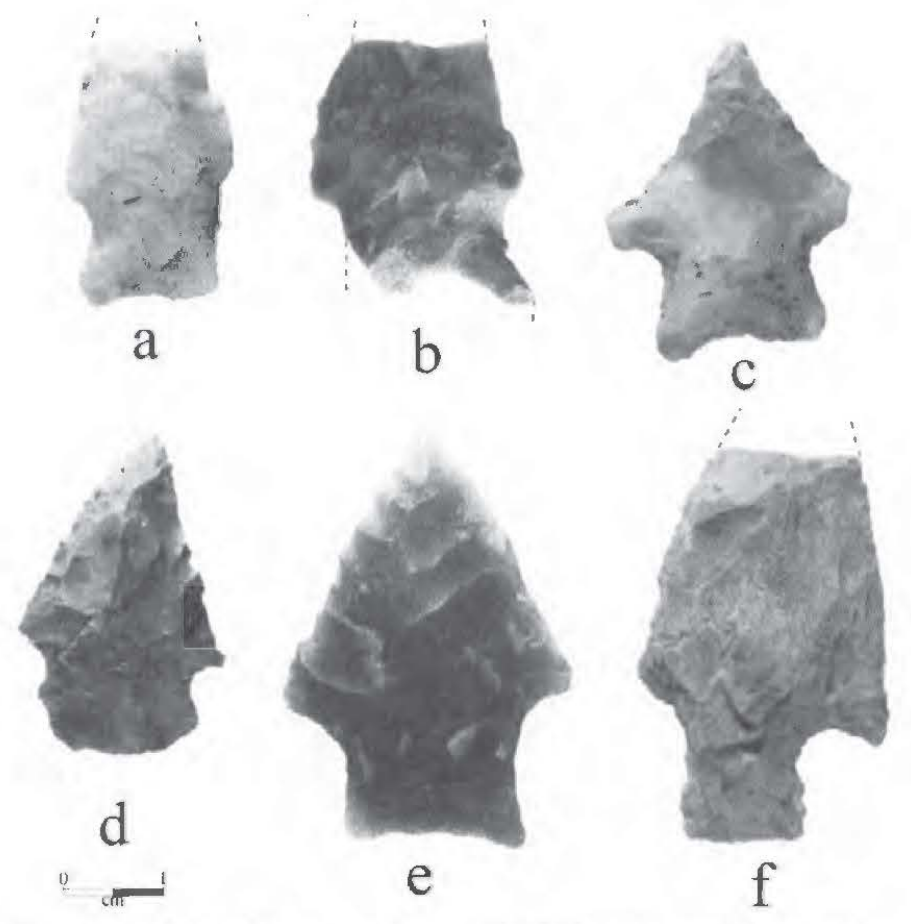

Figure 12. Other dart points from 41LR351: a, expanding stem dart point; b, Edgewood; c, Edgewood; d, Godley; e, Bulverde; f, Morrill. chert $(n=2)$, grayish-brown chert $(n=1)$, dark brown chert $(n=1)$, and brown chert $(n=1)$, likely all available in Red River gravel deposits, as well as a local quartzite $(\mathrm{n}=1)$.

There are 37 expedient flake tools with a variety of use-worn areas in the 41LR351 chipped stone tools, as well as five scrapers (Table 14). The majority of the flake tools and scrapers are from $0-50 \mathrm{~cm}$ bs $(70 \%)$, in what must assuredly be the prehistoric Caddo archaeological deposits; both gravers are from the same depths in the deposits. Only $24 \%$ of the flake tools and scrapers are from $60-100 \mathrm{~cm}$ bs, in what are probably primarily Woodland and Late Archaic archaeological deposits. These tools would have been used for scraping hides as well as cutting, shredding and graving wood, bone, and plant products by the aboriginal inhabitants of the site.

Table 14. Expedient flake tools and scrapers from 41LR351.

\begin{tabular}{llcc}
\hline $\begin{array}{l}\text { Provenience } \\
\text { (unit and } \mathrm{cm} \text { bs) }\end{array}$ & $\begin{array}{l}\text { Tool use } \\
\text { area/type }\end{array}$ & $\begin{array}{c}\text { UL } \\
(\mathrm{mm})\end{array}$ & Raw Material \\
\hline
\end{tabular}

\section{Flake tools}

N96 E55, 0-10

N97 E55, 0-10

N98 E55, 0-10

N99 E54, 0-10

N99 E55, 0-10

N100 E52, 0-10

N97 E55, 10-20

N100 E51, 10-20

N100 E52, 10-20

N10। E53, 10-20

N101 E53, 10-20

N95 E55, 20-30

N97 E55, 20-30

N97 E55, 20-30

N97 E55, 20-30

N99 E56, 20-30

N99 E56, 20-30

N96 E55, 30-40 bilateral and distal; graver tip

unilateral

unilateral

unilateral

unilateral

bilateral

distal

unilateral

unilateral

unilateral

bilateral

unilateral

bilateral

bilateral and graver tip

unilateral

bilateral

unilateral

bilateral
31.5

12.0

$14.2+$

13.9

10.6

-

13.0

$10.0+$

$12.0+$

12.5

25.6

10.8

$49.9+$

$25.0+$

7.5

22.5

9.7

29.0 white novaculite

brown chert

brown jasper

brown jasper

gray chert

quartzite

quartzite

white chert

dark brown chert

red jasper

quartzite

gray chert

quartzite

brown jasper

brown chert

brown jasper

brown jasper

brown jasper 
Table 14., cont.

\begin{tabular}{|c|c|c|c|}
\hline $\begin{array}{l}\text { Provenience } \\
\text { (unit and } \mathrm{cm} \mathrm{bs} \text { ) }\end{array}$ & $\begin{array}{l}\text { Tool use } \\
\text { area/type }\end{array}$ & $\begin{array}{c}\mathrm{UL} \\
(\mathrm{mm})\end{array}$ & Raw Material \\
\hline N97 E55, 30-40 & unilateral & 30.8 & brown jasper \\
\hline N99 E54, 30-40 & unilateral & $16.0+$ & white novaculite \\
\hline N98 E54, 40-50 & unilateral & 13.0 & brown jasper \\
\hline N99 E55, 40-50 & unilateral & 15.0 & gray novaculite \\
\hline N99 E58, 40-50 & distal & 7.0 & quartzite \\
\hline N101 E53, 40-50 & bilateral and distal & 58.0 & brown jasper \\
\hline N101 E53, 40-50 & unilateral & 8.1 & dark grayish-brown chert \\
\hline N100 E51, 50-60 & unilateral & 19.5 & black chert \\
\hline N101 E53, 50-60 & unilateral & 13.1 & quartzite \\
\hline N99 E58, 60-70 & unilateral & $21.0+$ & quartzite \\
\hline N100 E52, 60-70 & bilateral & - & Big Fork chert, green \\
\hline N100 E52, 60-70 & unilateral & 21.0 & grayish-brown chert \\
\hline N96 E55, 70-80 & unilateral and distal & 16.7 & brown jasper \\
\hline N101 E53, 70-80 & unilateral & 11.0 & grayish-brown chert \\
\hline N96 E55, 80-90 & bilateral & 27.0 & dark gray chert \\
\hline N97 E55, 80-90 & unilateral & - & brownish-gray chert \\
\hline N101 E53, 80-90 & unilateral & 13.1 & quartzite \\
\hline N101 E53, 80-90 & bilateral & $34.1+$ & white novaculite \\
\hline N101 E53, 90-100 & distal & 14.0 & dark grayish-brown chert \\
\hline \multicolumn{4}{|l|}{ Scrapers } \\
\hline N101 E53, 0-10 & side scraper & $9.3+$ & dark brown chert \\
\hline N101 E53, 10-20 & end scraper & 17.6 & white novaculite \\
\hline N96 E55, 40-50 & end/side scraper & 43.4 & brown jasper \\
\hline N98 E54, 40-50 & end/side scraper & 45.9 & black chert \\
\hline N98 E59, 70-80 & side scraper & $21.0+$ & very dark brown chert \\
\hline
\end{tabular}

$\mathrm{UL}=$ use-worn length

The use-worn length (UL) on the complete tools ranges from $17.6-45.9 \mathrm{~mm}$ for the scrapers; $7.0-14.0$ $\mathrm{mm}$ for distal retouched flake tools; 7.5-30.8 mm for flake tools with unilateral retouch/use-wear; and 22.5$58.0 \mathrm{~mm}$ for flake tools with bilateral retouch/use-wear (see Table 14).

Fifteen different lithic raw materials were selected for flake tool and scraper use, including red $(n=1)$ and brown jasper $(n=11)$, gray $(n=1)$ and white $(n=4)$ novaculite, 10 different colors of chert $(n=17)$, all but the brown chert from Ouachita Mountains/Red River gravel sources, and quartzite ( $n=8)$ (see Table 14). The Raw Material Retouch Index (RMRI, Orton 2008:1092) indicates that the following lithic raw materials in the 4 ILR351 assemblage were especially important, probably because of their predictability of fracture and 
the quality of the edge that could be produced on them for expedient flake and scraper use: white novaculite (RMRI=3.8), dark grayish-brown chert $(\mathrm{RMRI}=3.0)$, brown jasper $(\mathrm{RMR}=2.4)$, and grayish-brown chert (RMRI=1.3) .

Finally, a single white chert stemmed drill fragment was recovered in N99 E58, 50-60 cm bs. The drill bit is $6.0 \mathrm{~mm}$ thick.

\section{Hammerstones}

Both hammerstones in the assemblage (N95 E55, 80-90 cm bs and N98 E55, 10-20 cm bs) are made on a local quartzite. They are battered at one end and have flat poll ends. The hammerstones ranged from $41-63 \mathrm{~mm}$ in length, $35-38 \mathrm{~mm}$ in width, and $24-37 \mathrm{~mm}$ in thickness.

\section{Cores and Lithic Debris}

There are four cores in the lithic debris assemblage. The first, from N99 E58, 40-50 cm bs, is a brown chert tested cobble with two flake removals. The tested cobble has a stream-rolled cortex, and is $51 \times 53 \times$ $19 \mathrm{~mm}$ in length, width, and thickness. The second core is a multiple platform core of brown jasper from N100 E56, 30-40 cm bs; it measures $34 \times 32 \times 23 \mathrm{~mm}$ in length, width, and thickness. The third core (N96 E55, 50-60 cm bs) is a single platform corc on a grayish-brown chert. It has $6+1$ lake removals, and is $67 \mathrm{x}$ $38 \times 33 \mathrm{~mm}$ in length, width, and thickness. The last core is a bipolar core fragment of black chert from N95 E55, 60-70 cm bs; it has 5+ flake removals and measures $28 \times 15 \times 9 \mathrm{~mm}$ in length, width, and thickness.

Pieces of lithic debris of a wide variety of lithic raw materials are abundant in the 41LR35I archaeological deposits (Table 15). The mean number of pieces of lithic debris per level in all the units is 14.8. The highest densities of lithic debris occur in two peaks: $20-60 \mathrm{~cm}$ bs (19.1-21.1 pieces per level per unit) and $60-80 \mathrm{~cm}$ bs, with 23.6-30.4 pieces per level per unit. These peaks likely correspond to the Middle Caddo and Woodland/Late Archaic components at the site, although the latter two temporally distinct components cannot be readily separated by depth below the prehistoric Caddo occupation (see Figure 9).

Table 15. Lithic debris from 41LR351 by depth.

\begin{tabular}{llll}
\hline $\begin{array}{l}\text { Level } \\
(\mathrm{cm} \text { bs })\end{array}$ & No. & Percentage & Pieces per level \\
\hline $0-10$ & 170 & 8.3 & 14.2 \\
$10-20$ & 210 & 10.3 & 14.0 \\
$20-30$ & 338 & 16.6 & $\mathbf{2 1 . 1}$ \\
$30-40$ & 267 & 13.1 & $\mathbf{1 9 . 1}$ \\
$40-50$ & 279 & 13.6 & $\mathbf{1 9 . 9}$ \\
$50-60$ & 232 & 11.4 & $\mathbf{1 9 3}$ \\
$60-70$ & 212 & 10.4 & $\mathbf{2 3 . 6}$ \\
$70-80$ & 243 & 12.0 & 14.8 \\
$80-90$ & 74 & 3.6 & 11.0 \\
$90-100$ & 11 & 0.5 & 14.8 \\
\hline Totals & 2036 & 100.0 & \\
\hline
\end{tabular}

bolded numbers in the pieces per level column represent levels with significantly higher number of lithic debris pieces per level 
To obtain more specific information on the range of lithic raw materials that are represented in the lithic debris by depth, a sample of 485 pieces of lithic debris from $0-10 \mathrm{~cm}$ bs to $80-90 \mathrm{~cm}$ bs were quantified by level (Table 16). This is based on the detailed inspection of the lithic debris samples from 41LR351 tabulated in Table 17.

Table 16. Lithic raw materials in the lithic debris from 41LR351 by percentage and depth ( $n=485$ ).

\begin{tabular}{llllllll}
\hline $\begin{array}{l}\text { Depth } \\
\text { (cm bs) }\end{array}$ & NOV & QTZ & red J & brown J & Black C & local chert & OM chert \\
\hline $0-10$ & $4.0^{*}$ & 28.0 & 20.0 & 10.0 & $\mathbf{1 0 . 0}$ & 4.0 & \\
$10-20$ & 3.9 & 25.5 & 5.9 & 9.8 & 3.9 & $\underline{\mathbf{1 3 . 7}}$ & 2.0 \\
$20-30$ & $\mathbf{7 . 8}$ & $\mathbf{3 3 . 3}$ & $\mathbf{1 1 . 7}$ & 5.9 & 5.9 & 2.0 & 33.3 \\
$30-40$ & 3.5 & 26.3 & 8.8 & 5.3 & 5.3 & 8.8 & $\mathbf{4 0 . 4}$ \\
$40-50$ & 4.1 & 24.5 & 10.2 & $\underline{\mathbf{1 4 . 3}}$ & - & 10.2 & $\mathbf{3 6 . 7}$ \\
$50-60$ & 7.2 & 28.6 & 23.2 & 8.9 & 5.4 & 5.4 & 19.7 \\
$60-70$ & 1.7 & 28.8 & 8.4 & $\underline{\mathbf{2 0 . 3}}$ & 6.8 & 6.8 & 27.1 \\
$70-80$ & 3.6 & 26.8 & 1.8 & $\underline{\mathbf{1 4 . 3}}$ & $\mathbf{1 0 . 7}$ & 10.7 & 30.4 \\
$80-90$ & $\mathbf{2 . 1}$ & $\mathbf{3 8 . 2}$ & 7.3 & - & 7.3 & $\underline{\mathbf{1 0 . 9}}$ & 21.8 \\
\hline
\end{tabular}

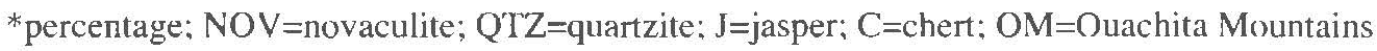

The raw materials represented in the lithic debris from 4ILR351 include both local and non-local sources. The local raw materials include coarse and fine-grained yuartzite, petrified wood (see Table 17), and earth-toned local cherts (red, yellowish-brown, and brown) probably found in local streams and interlluvial settings, while the non-local raw materials include several different colors of novaculite, red and brown jasper, and Ouachita Mountains cherts, among them black chert (Big Fork chert), and various combinations of white, gray, dark brown, grayish-brown, and brownish-gray cherts (see Table 17). The non-local lithic raw materials are likely available in the Red River gravels to the north of the site a few hours walk from the site. The highest proportion of local lithic raw materials in the lithic debris is at the bottom of the archaenlogical deposits ( $49.1 \%$ in $80-90 \mathrm{~cm}$ bs) and in $10-20 \mathrm{~cm}$ bs levels $(39.2 \%)$. In general, however, the proportions of local vs. non-local (Red River gravels) varied little in the archaeological deposits, indicating the continued use of the same lithic raw material sources for tool manufacture throughout the occupations at 41LR351.

Table 17. Lithic debris by raw material and cortex for sample of 485 pieces in the $41 \mathrm{LR351}$ assemblage.

\begin{tabular}{lllll}
$\begin{array}{l}\text { Provenience } \\
\text { (unit and cm bs) }\end{array}$ & Raw Material & $\begin{array}{l}\text { Cortical } \\
\text { No. }\end{array}$ & $\begin{array}{l}\text { Non-Cortical } \\
\text { No. }\end{array}$ & N \\
\hline N95 E55,0-10 & black chert & - & 1 & 1 \\
& dark gray chert & - & 1 & 1 \\
& gray chert & - & 1 & 1 \\
& red jasper & 2 & 2 & 4 \\
N96 E55,0-10 & quartzite & - & 3 & 3 \\
& black chert & 1 & 1 & 2 \\
& quartzite & 1 & - & 1 \\
& brown jasper & 1 & - & 3 \\
& red jasper & 2 & 1 & 1 \\
& dark gray chert & - & 1 & 1 \\
& white novaculite & - & 1 & 2 \\
& quartzite & 1 & 1 & 3 \\
& brown jasper & 1 & 2 & 1
\end{tabular}


Table 17., cont.

\begin{tabular}{|c|c|c|c|c|}
\hline $\begin{array}{l}\text { Provenience } \\
\text { (unit and } \mathrm{cm} \mathrm{bs} \text { ) }\end{array}$ & Raw Material & $\begin{array}{l}\text { Cortical } \\
\text { No. }\end{array}$ & $\begin{array}{l}\text { Non-Cortical } \\
\text { No. }\end{array}$ & $\mathrm{N}$ \\
\hline \multirow{14}{*}{ N99 E55, 0-10 } & black chert & - & 2 & 2 \\
\hline & brown chert & - & 1 & 1 \\
\hline & reddish-gray chert & 1 & - & 1 \\
\hline & dark gray novaculite & - & 1 & 1 \\
\hline & dark gray chert & - & 1 & 1 \\
\hline & red jasper & 1 & 1 & 2 \\
\hline & brown jasper & 1 & - & 1 \\
\hline & white-gray chert & 1 & - & 1 \\
\hline & quartzite & 3 & 5 & 8 \\
\hline & brown-red chert & - & 1 & 1 \\
\hline & dark grayish-brown chert & - & 2 & 2 \\
\hline & gray chert & 1 & 3 & 4 \\
\hline & Subtotal, $0-10 \mathrm{~cm}$ & 18 & 32 & 50 \\
\hline & & $36 \%$ & $64 \%$ & \\
\hline \multirow[t]{6}{*}{ N95 E55, 10-20 } & quartzite & 2 & - & 2 \\
\hline & white chert & 1 & - & 1 \\
\hline & gray novaculite & - & 1 & 1 \\
\hline & brown chert & 2 & - & 2 \\
\hline & red jasper & 1 & - & 1 \\
\hline & red-gray chert & 1 & - & 1 \\
\hline \multirow[t]{2}{*}{ N96 E55, 10-20 } & black chert & - & 1 & 1 \\
\hline & quartzite & 2 & - & 2 \\
\hline \multirow[t]{3}{*}{ N97 E60, 10-20 } & quartzite & 2 & 1 & 3 \\
\hline & brown chert & - & 1 & 1 \\
\hline & gray chert & - & 1 & 1 \\
\hline \multirow{7}{*}{ N99 E54, 10-20 } & quartzite & 1 & 3 & 4 \\
\hline & black chert & 1 & - & 1 \\
\hline & very dark brown chert & - & 3 & 3 \\
\hline & brown chert & 1 & 1 & 2 \\
\hline & brown jasper & - & 1 & 1 \\
\hline & red jasper & - & 1 & 1 \\
\hline & red chert & - & 1 & 1 \\
\hline \multirow[t]{7}{*}{ N99 E55, 10-20 } & white chert & - & 1 & 1 \\
\hline & brown jasper & 2 & 2 & 4 \\
\hline & grayish-brown chert & - & 1 & 1 \\
\hline & light gray chert & - & 2 & 2 \\
\hline & hrown chert & - & 1 & 1 \\
\hline & brownish-gray chert & - & 2 & 2 \\
\hline & quartzite & 1 & 4 & 5 \\
\hline \multirow[t]{5}{*}{ N99 E56, 10-20 } & gray chert & - & 1 & 1 \\
\hline & dark brown chert & - & 1 & 1 \\
\hline & red jasper & - & 1 & 1 \\
\hline & orange novaculite & - & 1 & 1 \\
\hline & quartzite & 2 & - & 2 \\
\hline \multirow[t]{2}{*}{ Subtotal, $10-20 \mathrm{~cm}$} & & 19 & 32 & 51 \\
\hline & & $37 \%$ & $63 \%$ & \\
\hline \multirow[t]{3}{*}{ N95 E55, 20-30 } & white novaculite & - & 1 & 1 \\
\hline & gray chert & - & 2 & 2 \\
\hline & dark brown chert & 1 & - & 1 \\
\hline
\end{tabular}


Table 17., cont.

\begin{tabular}{|c|c|c|c|c|}
\hline $\begin{array}{l}\text { Provenience } \\
\text { (unit and } \mathrm{cm} \text { bs) }\end{array}$ & Raw Material & $\begin{array}{l}\text { Cortical } \\
\text { No. }\end{array}$ & $\begin{array}{l}\text { Non-Cortical } \\
\text { No. }\end{array}$ & $\mathrm{N}$ \\
\hline \multirow{9}{*}{ N97 E60, 20-30 } & red jasper & 1 & 1 & 2 \\
\hline & gray novaculite & 1 & 1 & 2 \\
\hline & quartzite & 3 & 4 & 7 \\
\hline & red jasper & 2 & - & 2 \\
\hline & brown jasper & 2 & - & 2 \\
\hline & black chert & - & 2 & 2 \\
\hline & dark grayish-brown chert & 1 & - & 1 \\
\hline & brown-dark brown chert & 1 & - & 1 \\
\hline & gray chert & 1 & - & 1 \\
\hline \multirow{5}{*}{ N99 E55, 20-30 } & grayish-brown chert & 2 & - & 2 \\
\hline & quartzite & 1 & 4 & 5 \\
\hline & red jasper & - & 2 & 2 \\
\hline & black chert & - & 1 & 1 \\
\hline & dark gray chert & - & 1 & 1 \\
\hline \multirow{9}{*}{ N99 E56. 20-30 } & quartzite & - & 2 & 2 \\
\hline & dark brown chert & - & 2 & 2 \\
\hline & gray chert & - & 1 & 1 \\
\hline & brown-dark brown chert & 1 & 1 & 2 \\
\hline & quartzite & 2 & 1 & 3 \\
\hline & dark grayish-brown chert & 1 & & 1 \\
\hline & gray novaculite & - & 1 & 1 \\
\hline & brown jasper & 1 & - & 1 \\
\hline & red chert & - & 1 & 1 \\
\hline \multirow{3}{*}{ Subtotal, $20-30 \mathrm{~cm}$} & gray chert & - & 1 & 1 \\
\hline & & 21 & 29 & 50 \\
\hline & & $42 \%$ & $58 \%$ & \\
\hline \multirow[t]{6}{*}{ N95 E55. 30-40 } & red jasper & 1 & 1 & 2 \\
\hline & black chert & 1 & - & 1 \\
\hline & brown jasper & - & 2 & 2 \\
\hline & dark brown chert & 1 & 3 & 4 \\
\hline & gray chert & - & 2 & 3 \\
\hline & quartzite & - & 2 & 2 \\
\hline \multirow[t]{8}{*}{ N97 E60, 30-40 } & orange novaculite & 1 & - & 1 \\
\hline & gray novaculite & - & 1 & 1 \\
\hline & gray chert & - & 1 & 1 \\
\hline & black chert & 1 & 1 & 2 \\
\hline & brown chert & 1 & 3 & 4 \\
\hline & quartzite & 1 & 5 & 6 \\
\hline & red-gray chert & 1 & & 1 \\
\hline & quartz & - & 1 & 1 \\
\hline \multirow[t]{6}{*}{ N99 E56, 30 40 } & quartzite & 1 & 2 & 3 \\
\hline & brown jasper & 1 & - & 1 \\
\hline & brown chert & 1 & - & 1 \\
\hline & red jasper & - & 1 & 1 \\
\hline & dark brown chert & - & 1 & 1 \\
\hline & gray-white chert & - & 1 & \\
\hline \multirow[t]{4}{*}{ N99 E58. 30-40 } & quartzite & 1 & 3 & 4 \\
\hline & dark brown chert & - & 2 & 2 \\
\hline & red jasper & 1 & 1 & 2 \\
\hline & grayish-brown chert & 1 & - & 1 \\
\hline
\end{tabular}


Table 17., cont.

\begin{tabular}{|c|c|c|c|c|}
\hline $\begin{array}{l}\text { Provenience } \\
\text { (unit and } \mathrm{cm} \mathrm{bs} \text { ) }\end{array}$ & Raw Material & $\begin{array}{l}\text { Cortical } \\
\text { No. }\end{array}$ & $\begin{array}{l}\text { Non-Cortical } \\
\text { No. }\end{array}$ & $\mathrm{N}$ \\
\hline & dark gray chert & - & 7 & 7 \\
\hline & gray chert & - & 3 & 3 \\
\hline \multirow[t]{2}{*}{ Subtotal, $30-40 \mathrm{~cm}$} & & 14 & 43 & 57 \\
\hline & & $25 \%$ & $75 \%$ & \\
\hline \multirow[t]{7}{*}{ N95 E55, 40-50 } & quartzite & 1 & 1 & 2 \\
\hline & red jasper & - & 2 & 2 \\
\hline & brown jasper & - & 3 & 3 \\
\hline & white chert & 1 & - & 1 \\
\hline & yellowish-brown chert & - & 1 & 1 \\
\hline & gray novaculite & - & 1 & 1 \\
\hline & dark brown chert & - & 3 & 3 \\
\hline \multirow[t]{8}{*}{ N96 E55. 40-50 } & quartzite & 2 & 1 & 3 \\
\hline & brown jasper & 1 & 1 & 2 \\
\hline & light gray chert & - & 1 & 1 \\
\hline & dark brown chert & - & 1 & 1 \\
\hline & gray chert & 1 & 1 & 2 \\
\hline & dark gray chert & 1 & 2 & 3 \\
\hline & red chert & - & 1 & 1 \\
\hline & red jasper & - & 2 & 2 \\
\hline \multirow{6}{*}{ N99 E55, 40-50 } & brown jasper & - & 1 & 1 \\
\hline & light gray chert & - & 1 & 1 \\
\hline & grayish-brown chert & 1 & - & 1 \\
\hline & quartzite & - & 1 & 1 \\
\hline & gray novaculite & - & 1 & 1 \\
\hline & gray chert & 1 & 2 & 3 \\
\hline \multirow[t]{5}{*}{ N99 E56, 40-50 } & dark brown chert & 1 & 1 & 2 \\
\hline & brown chert & 3 & - & 3 \\
\hline & brown jasper & 1 & - & 1 \\
\hline & red jasper & 1 & - & 1 \\
\hline & quartzite & 4 & 2 & 6 \\
\hline \multirow{2}{*}{ Subtotal, $40-50 \mathrm{~cm}$} & & 19 & 30 & 49 \\
\hline & & $39 \%$ & $61 \%$ & \\
\hline \multirow[t]{4}{*}{ N95 E55, 50-60 } & gray chert & 1 & - & 1 \\
\hline & red jasper & 1 & 4 & 5 \\
\hline & dark gray chert & - & 1 & 1 \\
\hline & quartzite & 1 & 1 & 2 \\
\hline \multirow[t]{7}{*}{ N96 E55, 50-60 } & petrified wood & - & 1 & 1 \\
\hline & quartzite & 4 & 3 & 7 \\
\hline & red jasper & 2 & 1 & 3 \\
\hline & black chert & - & 1 & 1 \\
\hline & brown jasper & - & 1 & 1 \\
\hline & dark gray chert & 1 & 1 & 2 \\
\hline & dark brown chert & - & 1 & 1 \\
\hline \multirow[t]{6}{*}{ N99 E54, 50-60 } & black chert & - & 1 & 1 \\
\hline & gray novaculite & - & 1 & 1 \\
\hline & dark gray novaculite & - & 1 & 1 \\
\hline & white chert & - & 1 & 1 \\
\hline & red jasper & 1 & 2 & 3 \\
\hline & brown jasper & 2 & 2 & 4 \\
\hline
\end{tabular}


Table 17., cont.

\begin{tabular}{|c|c|c|c|c|}
\hline $\begin{array}{l}\text { Provenience } \\
\text { (unit and } \mathrm{cm} \mathrm{bs} \text { ) }\end{array}$ & Raw Material & $\begin{array}{l}\text { Cortical } \\
\text { No. }\end{array}$ & $\begin{array}{l}\text { Non-Cortical } \\
\text { No. }\end{array}$ & $\mathbf{N}$ \\
\hline & brown chert & 1 & 1 & 2 \\
\hline & dark gray chert & - & 2 & 2 \\
\hline & quartzite & 2 & 2 & 4 \\
\hline \multirow{8}{*}{ N99 E55, 50-60 } & quartzite & - & 3 & 3 \\
\hline & black chert & - & 1 & 1 \\
\hline & grayish-brown chert & 1 & - & 1 \\
\hline & white novaculite & - & 2 & 2 \\
\hline & red jasper & - & 2 & 2 \\
\hline & yellowish-brown chert & - & 1 & 1 \\
\hline & gray chert & - & 1 & 1 \\
\hline & dark grayish-brown chert & - & 1 & 1 \\
\hline \multirow[t]{2}{*}{ Subtotal, $50-60 \mathrm{~cm}$} & & 17 & 39 & 56 \\
\hline & & $30 \%$ & $70 \%$ & \\
\hline \multirow[t]{9}{*}{ N95 E55, 60-70 } & quartzite & 4 & 1 & 5 \\
\hline & brown chert & - & 2 & 2 \\
\hline & brown jasper & 1 & - & 1 \\
\hline & red jasper & - & 1 & 1 \\
\hline & dark gray chert & 1 & - & 1 \\
\hline & black chert & - & 1 & 1 \\
\hline & grayish-brown chert & - & 2 & 2 \\
\hline & light gray chert & - & 1 & 1 \\
\hline & gray chert & - & 1 & 1 \\
\hline \multirow[t]{8}{*}{ N97 E55, 60-70 } & $\begin{array}{l}\text { Big Fork chert, } \\
\text { green }\end{array}$ & 1 & - & 1 \\
\hline & dark grayish-brown chert & - & 1 & 1 \\
\hline & brown chert & 2 & - & 2 \\
\hline & light gray chert & 1 & - & 1 \\
\hline & brown jasper & 4 & 1 & 5 \\
\hline & quartzite & 3 & 4 & 7 \\
\hline & black chert & - & 2 & 2 \\
\hline & grayish-brown chert & - & 2 & 2 \\
\hline \multirow[t]{5}{*}{ N98 E54, 60-70 } & black chert & 1 & - & 1 \\
\hline & red jasper & 1 & - & 1 \\
\hline & brown jasper & 2 & - & 2 \\
\hline & gray-black chert & 1 & - & 1 \\
\hline & grayish-brown chert & 1 & 1 & 2 \\
\hline \multirow[t]{7}{*}{ N99 E54, 60-70 } & white novaculite & - & 1 & 1 \\
\hline & white chert & - & 1 & 1 \\
\hline & very dark brown chert & - & 1 & 1 \\
\hline & reddish-gray chert & 1 & - & 1 \\
\hline & red jasper & 1 & 2 & 3 \\
\hline & brown jasper & 4 & - & 4 \\
\hline & quartzite & 4 & 1 & 5 \\
\hline \multirow[t]{2}{*}{ Subtotal, $60-70 \mathrm{~cm}$} & & 33 & 26 & 59 \\
\hline & & $56 \%$ & $44 \%$ & \\
\hline \multirow[t]{5}{*}{ N95 E55, 70-80 } & quartzite & 3 & 8 & 11 \\
\hline & red jasper & - & 1 & 1 \\
\hline & black chert & - & 2 & 2 \\
\hline & dark grayish-brown chert & - & 1 & 1 \\
\hline & brown chert & 2 & 1 & 3 \\
\hline
\end{tabular}


Table 17., cont.

\begin{tabular}{|c|c|c|c|c|}
\hline $\begin{array}{l}\text { Provenience } \\
\text { (unit and } \mathrm{cm} \text { bs) }\end{array}$ & Raw Material & $\begin{array}{l}\text { Cortical } \\
\text { No. }\end{array}$ & $\begin{array}{l}\text { Non-Cortical } \\
\text { No. }\end{array}$ & $\mathrm{N}$ \\
\hline \multirow{16}{*}{ N98 E54, 70-80 } & brown jasper & - & 1 & 1 \\
\hline & dark gray chert & 1 & - & 1 \\
\hline & gray novaculite & - & 1 & 1 \\
\hline & petrified wood & - & 1 & 1 \\
\hline & grayish-brown chert & - & 1 & 1 \\
\hline & quartzite & 3 & 1 & 4 \\
\hline & white novaculite & - & 1 & 1 \\
\hline & white chert & - & 1 & 1 \\
\hline & grayish-brown chert & - & 2 & 2 \\
\hline & brown chert & - & 2 & 2 \\
\hline & brown jasper & 7 & - & 7 \\
\hline & black chert & - & 4 & 4 \\
\hline & dark gray chert & 2 & 4 & 6 \\
\hline & gray chert & - & 4 & 4 \\
\hline & yellowish-brown chert & 1 & - & 1 \\
\hline & brown-dark brown chert & - & 1 & 1 \\
\hline N100 E51, 70-80 & quartz & - & 1 & 1 \\
\hline \multirow[t]{2}{*}{ Subtotal. $70-80 \mathrm{~cm}$} & & 19 & 38 & 57 \\
\hline & & $33 \%$ & $67 \%$ & \\
\hline \multirow[t]{8}{*}{ N95 E55, 80-90 } & quartz & - & 1 & 1 \\
\hline & red jasper & 1 & 1 & 2 \\
\hline & brown-dark brown chert & 1 & - & 1 \\
\hline & petrified wood & - & 1 & 1 \\
\hline & gray novaculite & 1 & - & 1 \\
\hline & gray chert & 1 & - & 1 \\
\hline & yellowish-brown chert & 2 & - & 2 \\
\hline & quartzite & 2 & 2 & 4 \\
\hline \multirow[t]{5}{*}{ N96 E55, 80-90 } & black chert & 1 & 2 & 3 \\
\hline & white novaculite & - & 2 & 2 \\
\hline & quartzite & 4 & 4 & 8 \\
\hline & dark brown chert & - & 3 & 3 \\
\hline & brown chert & - & 2 & 2 \\
\hline \multirow[t]{11}{*}{ N99 E58, 80-90 } & black chert & 1 & - & 1 \\
\hline & white novaculite & - & 1 & 1 \\
\hline & dark gray novaculite & - & 1 & 1 \\
\hline & red jasper & 1 & 1 & 2 \\
\hline & grayish-brown chert & - & 1 & 1 \\
\hline & brown novaculite & 1 & - & 1 \\
\hline & light gray chert & - & 1 & 1 \\
\hline & gray chert & 1 & 3 & 4 \\
\hline & very dark brown chert & - & 1 & 1 \\
\hline & brown chert & 1 & 1 & 2 \\
\hline & quartzite & 4 & 5 & 9 \\
\hline \multirow[t]{2}{*}{ Subtutal, $80-90 \mathrm{~cm}$} & & 21 & 33 & 54 \\
\hline & & $39 \%$ & $61 \%$ & \\
\hline
\end{tabular}

Looking more specifically at the proportion of the different lithic raw materials in the lithic debris (see Tables 16 and 17), in the deepest archaeological deposits (i.e., $60-90 \mathrm{~cm}$ bs), the most common raw materials being knapped for tools were quartzite (26.8-38.2\% by level), Ouachita Mountains cherts (21.8-30.4\%), and brown jasper (14.3-20.3\%). Black chert and local cherts were generally better represented in the deeper 
archaeological deposits than they were in the upper prehistoric Caddo archaeological deposits, and they represented between $6.8-10.9 \%$ of the lithic debris in these depths. Novaculite was particularly common $(9.1 \%)$ in the bottom level of the archaeological deposits (see Tablc 16).

In the upper 0-60 cm bs, Ouachita Mountains cherts were the best represented in the lithic debris - 19.7$40.4 \%$--followed by quartzite (24.5-33.3\%), red jasper (5.9-23.2\%), and brown jasper (5.3-14.3\%). Black chert (Big Fork chert) accounts for between $0.0-10.0 \%$ of the lithic debris in the upper deposits, compared to $2.0-13.7 \%$ local cherts, and $3.5-7.8 \%$ novaculite. Novaculite, red jasper, black chert, and local cherts are particularly common between $0-30 \mathrm{~cm}$ bs (see Tables 16 and 17).

Cortical pieces of lithic debris - evidence of the on-site knapping and reduction of pebbles and cobbles of different raw materials - are common in the 41LR351 lithic debris assemblage. By level, the percentage of cortical flakes ranges from $25-42 \%$ in the $0-60 \mathrm{~cm}$ bs archaeological deposits, and $33-56 \%$ in the $60-90$ $\mathrm{cm}$ bs levels (see Table 17). The considerable proportions of cortical flakes in all size grades suggests that the chipped stone tool knapping on this site was primarily the result of both tool retouching and resharpening and pressure flaking of already completed tools that had been brought to the site from both local and non-local sources, as well as the regular initial thinning and shaping (with soft and hard hammer percussion flakes) of picces (pebbles, cobbles, and bifaces from source locations) that still had cortical remnants that needed to be removed for tool manufacture.

The proportion of cortical pieces varies among the different lithic raw materials and source areas represented in the lithic debris (Table 18). The highest proportion of cortical flukes occur among the red and brown jasper $(54.0 \%)$ and the local raw material sources $(46.7 \%)$, especially the quartzite and the yellowishbrown chert. These materials were more often subject to the initial reduction of pebbles and cobbles, either to obtain usable flakes for tool manufucture (especially arrow points, dart points made on flakes, and tlake tools/scrapers) or from the direct reduction of pebbles and cobbles for bifaces and most dart points.

Table 18. Cortical percentages by lithic debris raw materials.

\begin{tabular}{lll}
\hline Raw material & No. & Percent \\
\cline { 1 - 1 } Local Sources & & \\
quartzite & 140 & 48.6 \\
brown chert & 30 & 46.7 \\
yellowish-brown chert & 5 & 60.0 \\
brown-red chert & 1 & - \\
red chert & 3 & - \\
petrified wood & 3 & 46.7 \\
Subtotal, local sources & 182 & \\
Red River Gravels/Ouachita Mountains Sources & & \\
red jasper & & 42.3 \\
brown jasper & 52 & 66.7 \\
Subtotal, jasper & 48 & 54.0 \\
black chert & 100 & 23.3 \\
dark gray chert & & 22.2 \\
dark brown chert & 30 & 14.3 \\
gray chert & 27 & 25.0
\end{tabular}


Table 18., cont.

\begin{tabular}{lll}
\hline Raw material & No. & Percent Cortical \\
\hline brown-dark brown chert & 5 & 60.0 \\
light gray chert & 7 & 28.6 \\
grayish-brown chert & 16 & 37.5 \\
brownish-gray chert & 2 & - \\
white chert & 6 & 33.3 \\
dark grayish-brown chert & 7 & 28.6 \\
white-gray chert & 2 & 50.0 \\
Big Fork chert, green & 1 & 100.0 \\
very dark brown chert & 5 & - \\
reddish-gray chert & 4 & 100.0 \\
gray-black chert & 1 & 100.0 \\
Subtotal, Ouachita Mountains cherts & 170 & 27.1 \\
& & 50.0 \\
orange novaculite & 2 & 30.0 \\
gray novaculite & 10 & - \\
white novaculite & 9 & - \\
dark gray novaculite & 3 & 100.0 \\
brown novaculite & 1 & 24.0 \\
Subtotal, novaculite & 25 & - \\
\hline quartz & 3 & 39.4 \\
\hline Totals & 485 & \\
\hline
\end{tabular}

By contrast, none of the quartz pieces are cortical, only $24 \%$ of the novaculite lithic debris has cortical remnants, and $27.1 \%$ of the Ouachita Mountains chert lithic debris are cortical pieces (see Table 18). These raw materiais were more likely to have been knapped and reduced at source locations along Red River gravel sources to remove cortical remnants than were the local raw materials and the jasper, and it is likely that completed tools of these Ouachita Mountains/Red River gravel materials knapped elsewhere were brought to 41 LR351 and used/resharpened on a regular basis during the various prehistoric occupations.

\section{SUMMARY AND CONCLUSIONS}

Recent excavations by the Valley of the Caddo Archeological Society at 4ILR35I in the Pine Creek drainage basin in northern Lamar County, Texas have recovered archaeological evidence of use of the sitc area from as early as ca. 6000 years ago to as late as ca.A.D. 1300 . The site was sporadically used for huntinggathering-foraging activities during much of that time, based on the recovery of a number of Woodland and Late Archaic dart points and various bifacial and flake tools. No features or midden deposits are associated with these earlier occupations. However, between ca. A.D. 1150 to ca. A.D. 1300, the site was the home of a Caddo farmstead, one that was probably occupied by an extended family for one or more generations (ca. 20 years per generation). The farmstead is marked by the remains of a burned wattle and daub structure, a substantial ceramic assemblage, along with a number of flake tools, scrapers, chipped stone arrow points and arrow point preforms $(\mathrm{n}=10)$ and a flake drill.

The sherd assemblage from the prehistoric Middle Caddo period occupation includes 823 plain rim, body, and base sherds as well as 159 decorated rim and body sherds. These sherds are from hand-made and coiled pottery and include engraved and red-slipped fine wares, incised, punctated, and incised-punctated utility 
wares, and plain ware vessels. Based on the rim sherds, about $60 \%$ of the vessels made and used at 41LR351 are decorated, and of these, approximately $62 \%$ are utility wares decorated with incised, incised-punctated, punctated, and appliqued decorative elements. Red-slipped fine wares are also relatively abundant in the fine wares, which is a known feature of Middle Caddo period (ca. A.D. 1100-1300) ceramic assemblages in this part of the Red River basin (Perttula 2008, ed.; Prikryl 2008). Identified or provisionally identified ceramic types in the 4ILR351 assemblage are Sanders Engraved, Holly Fine Engraved, Sanders Plain, Canton Incised, and Pennington Punctated-Incised.

The sherds from 4ILR351 are from vessels that are tempered primarily with grog (crushed pieces of fired clay), but burned bone, and/or crushed pieces of hematitc or a hematitic sandstone are also important tempering agents. Vessel forms represented in the collection are carinated bowls, compound bowls, simple open bowls, bottles, and jars. The vessels have typically bcen fired in a reducing or low oxygen environment and then cooled in the open air. Vessels are smoothed, but only rarely burnished, on one or both vessel surfaces. These vessels have thick, flat, bases more than $10 \mathrm{~mm}$ in thickness, but mean vessel rim and body walls for all three wares range between 6.16-7.39 mm; no obvious thick Williams Plain (see Brown 1996; Schambach 1998) vessel sherds have been identified in the 41LR351 plain wares.

The ceramic assemblage at 41LR351 shares many characteristics with other prehistoric Caddo ceramic assemblages of Middle Caddo period age in the middle reaches of the Red River basin (i.e., that portion of the Red River just below, and then above, the confluence with the Kiamichi River, but within forested areas of Northeast Texas), the lower reaches of the Kiamichi River basin in southeastern Oklahoma, and the upper South Sulphur River basin. These ceramic assemblages, including 4ILR351, appear to date from ca. A.D. 1150 to ca. A.D. 1300 , although none of the sites are well-dated through the use of radiocarbon assays, and also they predate the use of shell-tempered pottery in these areas, as that technological feature does not become a predominant part of local Caddo ceramic assemblages until around the 14th century (see Perttula et al. 2012). In the past, these sites have been included in the now outdated Sanders focus or phase (see Krieger 1946), but currently there is no accepted cultural taxonomic unit for sites of this age and cultural affiliation in this part of Northeast Texas or southeastern Oklahoma.

These sites have grog-tempered assemblages with engraved and red-slipped fine wares (including Sanders Engraved, Sanders Plain, Maxey Noded Redware, and Holly Fine Engraved), a variety of decorated utility wares (among them Canton Incised, Crockett Curvilinear Incised, Pennington Punctated Incised, and punctated vessels such as Monkstown Fingernail Impressed), and plain slipped and non-slipped wares (not notably thick-walled) are relatively common. The relevant sites on the Red River include Holdeman (41RR11) (Perttula 2008b), Sam Kaufman/Roitsch (41RR16) (Skinner et al. 1969; Perttula 2008, ed.), Fasken (41RR14) (Prikryl 2008), and Sanders (41LR2) (Krieger 1946, 2000) in Texas, and the Nelson (34Ch6) and Cook (34Ch7) sites in southeastern Oklahoma (Rohrbaugh 1973:184-193; Wyckoff and Fisher 1985:Figures 2 and 30); the Pat Boyd (34Ch113), Hugo Dam (34Ch112), and Mahaffey (34Ch1) sites on the lower Kiamichi River (Burton 1970; Rohrbaugh 1973; Perino and Bennett 1978); the Snapping Turtle (41LR11), Weekend Warrior (41LR31), and Cundleff (41LR29) sites on Sanders Creek (Lorrain and Hoffrichter 1968); A. C. Mackin (41RR36) and Neely (41RR61) on Big Pine Creek (Mallouf 1976); and Hurricane Hill (41 HP106) in the upper reaches of the South Sulphur River (Perttula 1999).

Examining in more detail the characteristics of ceramic assemblages in Red River and Lamar counties, Texas, including 41LR351, it is possible to recognize temporal differences between them (Table 19). The earlier components include the Ray site (Bruseth et al. 2001) and 41LR297 (Perttula 2008a). These are plain ware-dominated and grog and bone-tempered ceramic assemblages. At the Ray site, which has nine calibrated radiocarbon dates that range from A.D. 700-1200 (Bruseth et al. 2001:Table 1I) - with six that postdate A.D. 1000 - the P/DR value is 56.6:1. Site 4lLR297 has no radiocarbon dates, but the Caddo occupation there appears to pre-date ca. A.D. 1150. With respect to the different kinds of decorated sherds found in these Early Caddo assemblages, incised decorative elements predominate. These incised vessels have primarily simple straight line and geometric designs, with a number of horizontally incised rims, including rims from 
Coles Creek Incised vessels along with Caddo types such as Davis Incised, Dunkin Incised, and Kiam Incised. Incised and incised-punctated elements from Crockett Curvilinear Incised vessels are also important constituents of these Early Caddo ceramic assemblages, and Coles Creek Incised vessel sherds are present at both Ray and 4ILR297. Engraved sherds from Hickory and Holly Fine Engraved vessels comprise 30\% of the decorated sherds at 41LR297. Red-slipped sherds are not present in that assemblage.

'Table 19. Comparisons of the $41 \mathrm{LR35I}$ ceramic assemblage with selected nearby prehistoric Caddo ceramic assemblages in the Red River basin in Northeast Texas.

\begin{tabular}{|c|c|c|c|c|}
\hline \multirow[t]{2}{*}{ Assemblage Attributes } & \multicolumn{4}{|c|}{ Sites } \\
\hline & Ray & $\begin{array}{c}\text { Sam } \\
\text { Kaufman* }\end{array}$ & 41LR297 & 41LR351 \\
\hline Decorated sherds & 101 & 163 & 88 & 159 \\
\hline Plain sherds & 5719 & 792 & 1255 & 823 \\
\hline $\mathrm{P} / \mathrm{DR}$ & $56.6: 1$ & $4.86: 1$ & 14.3:1 & $5.18: 1$ \\
\hline Grog temper $\%$ & 73 & 94 & $90 * *$ & $96^{* * *}$ \\
\hline Bone temper \% & 27 & 6 & $32 * *$ & $17^{* *}$ \\
\hline Incised sherds & 83 & 63 & 40 & 74 \\
\hline Punctated sherds & 14 & 19 & 13 & 15 \\
\hline Incised-punctated sherds & - & 2 & 8 & 9 \\
\hline Appliqued sherds & - & - & - & 1 \\
\hline Brushed sherds & 3 & - & - & - \\
\hline Engraved sherds & 1 & 1 & 27 & 39 \\
\hline Red-slipped & - & 70 & - & 21 \\
\hline Coles Creek Incised & + & + & + & \\
\hline Crockett Curvilinear Incised & + & + & + & \\
\hline French Fork Incised & + & + & & \\
\hline Hickory/Holly Engraved & + & + & & \\
\hline Williams Plain & + & + & & \\
\hline
\end{tabular}

*East Mound (Skinner et al. 1969:Tables 5 and 6)

** percentages do not total to $100 \%$ because many sherds have more than one tempering agent $+=$ present

Later, ca. A.D. 1100-1300, Caddo ceramic assemblages are present in the East Mound at the Sam Kautman site and 4lLR351. Excavations at the East Mound at Sam Kaufman recovered a ceramic assemblage from archaeological deposits (House 3) with four calibrated dates: their mean age ranges from A.D. 1008-1206 (Perttula 1998:334). The P/DR of this assemblage is 4.86:1 (see Table 19), quite comparable to the P/DR of 5.18:1 from 4ILR351, and both have considerably lower P/DR values than do the pre-A.D. 1100/1150 assemblages at the Ray site and 41LR297 (14.3:1 to 56.6:1). These post-ca. A.D. 1100 Caddo ceramic assemblages apparently have at least three times the percentage of decorated vessels and vessel sherds when compared to their pre-A.D. 1100 counterparts in the same region. Red-slipped sherds are also common in both post-A.D. 1100 assemblages (see Table 15). Finally, the use of bone temper by Caddo potters appears to have decreased from pre-A.D. $1100(27-32 \%)$ to post-A.D. $1100(6-17 \%)$ contexts.

Hopefully, future excavations at the site will obtain more specific information on the characteristics of the red clay floor and associated burned house deposits in the prehistoric Caddo component - in conjunction 
with detailed information on the range and kind of ceramic and lithic artifact classes found in those deposits. Associated plant and animal remains from this component should be fully studied and reported, and a suite of radiocarbon dates from these deposits will help confirm (or refute) the estimated age of the Caddo component at 41LR351. Likewise, excavations in the Woodland and Late Archaic deposits found generally below the Caddo archaeological deposits should be designed with the goal of attempting to stratigraphically parse the two components, and obtain more specific information on the artifact assemblages that can be associated with both occupations. Here too, radiocarbon dates should be obtained on charred plant remains from the lower archaeological deposits $(60-90 \mathrm{~cm}$ bs) to establish the absolute age of the Woodland and Late Archaic components at 41LR351.

\section{ACKNOWLEDGMENTS}

I would like to thank the Valley of the Caddu Archaeological Socicty, especially Gary Sykes, for the opportunity to study all the prehistoric artifacts from 4IL.R35I. I ance Trask took the digital phutographs of selected sherds, daub, and projectile points to accompany this report, and prepared the figures.

\section{REFERENCES CITED}

Brown, J. A.

1996 The Spiro Ceremonial Center: The Archaeology of Arkansas Valley Caddoan Culture in Eastern Oklahoma. 2 Vols. Memoirs No. 29. Museum of Anthropology. University of Michigan, Ann Arbor.

Bruseth, J. E. and T. K. Perttula, with contributions by G. J. Fritz and B. C. Yates

2006 Archeological Investigations at the HudnalI-Pirtle Site (4IRK4): An Early Caddo Mound Center in Northeast Texas. Caddo Archeology Journal 15:57-I58.

Bruseth, J. E., L., Banks, and J. Smith

2001 The Ray Site (41LR135). Bulletin of the Texas Archeological Society 72:197-213.

Bruseth, J., J. Durst, R. Proctor, L. Banks, G. Sykes, and B. Pierson

2009 Investigations at the Gene and Ruth Ann Stallings Ranch Site (41LR297). Bulletin of the Texas Archeolngical Society 80:195-205.

Burton, S. S.

1970 The Hugo Dam Site, Ch-112, Choctaw County, Southeast Oklahoma. Archaeological Site Report No. 16. Oklahoma River Basin Survey. University of Oklahoma Research Institute, Norman.

Dowd, E. L.

2011 Sourcing Red River Jasper: An Archaeological and Geological Investigation of a Gravel Chert in the Red River Drainage. Caddo Archeology Journal 21:89-106.

Duncan, M., L. Neal, D. Shockey. D. Wyckoff, M. Sullivan, and L. M. Sullivan

2007 Southern Plains Lithics: The. Small Points. Special Bulletin No. 26. Oklahoma Anthropological Society, Norman.

Hoffman, M. P.

1967 Ceramic Pipe Style Chronology Along the Red River Drainage in Southwestern Arkansas. The Arkansas Archeologist 8(1):4-14. 
Krause, R. A.

2007 A Potter's Tale. In Plains Village Archaeology: Bison-hunting Farmers in the Central and Northern Plains, edited by S. A. Ahler and M. Kay, pp. 32-40. University of Utah Press, Salt Lake City.

Krieger, A. D.

1946 Culture Complexes and Chronology in Northern Texas With Extensions of Puebloan Datings to the Mississippi Valley. Publication No. 4640. The University of Texas at Austin.

2000 The Pottery of the Sanders Farm. In The 1931 Excavations at the Sanders Site, Lamar County, Texas: Notes on the Fieldwork, Human Osteology, and Ceramics, by A. T. Jackson, M. S. Goldstein, and A. D. Krieger, pp. 131-144. Archival Series 2. Texas Archeological Research Laboratory, The University of Texas at Austin,

Lorrain, D. and N. Hoffrichter

1968 Archeological Survey and Excavation at Pat Mayse Reservoir, Texas. Report submitted to the National Park Service by Southern Methodist University, Dallas.

Mallouf, R. J.

1976 Archeological Investigations at Proposed Big Pine Lake, 1974, 1975, Lumar and Red River Counties, Texas. Archeological Survey Report 18. Texas Historical Commission, Austin.

O'Brien, M. J., T. D. Holland, R. J. Hoard, and G. L. Fox

1994 Evolutionary Implications of Design and Performance Characteristics of Prehistoric Pottery. Journal of Archaeological Method and Theory 1:259-304.

Orton, J.

2008 A useful measure of the desirability of different raw materials for retouch within and between assemblages: the raw material retouch index. Journal of Archaeological Science 35 (2008): 1090-1094.

Perino, G. and W. J. Bennett, Jr.

1978 Archaeological Investigations at the Mahaffey Site, Ch-1, Hugo Reservoir, Choctaw County, Oklahoma. Museum of the Red River, Idabel, Oklahoma.

Perttula, T. K.

1998 A Compendium of Radiocarbon and Oxidizable Carbon Ratio Dates from Archaeological Sites in East Texas, with a Discussion of the Age and Dating of Select Components and Phases. Radiocarbon 39(3):305-341.

2004 The Prehistoric and Caddoan Archeology of the Northeastern Texas Pineywoods. In The Prehistory of Texas, edited by T. K. Perttula, pp. 370-407. Texas A\&M University Press, College Station.

2008a The Decorated Ceramic Sherds, Plain Rinss, and Clay Pipe Sherds lrom the Stallings Site (4 ILR297), Lamar County, Texas. MS on file with the author.

2008bArcheological Survey of the Roitsch Farm and Adjoining Lands, 1991 and 1992 Texas Archeological Society Field School, Red River County, Texas. In Collected Papers from Past Texas Archeological Society Summer Field Schools, edited by T. K. Perttula, pp. 173-312. Special Publication No. 5. Texas Archeological Society, San Antonio.

2010 Analysis of the Prehistoric Caddo Ceramics from 41LR351, Lanrar County, Texas. Journal of Northeast Texas Archaeology 33:69-91. 
Perttula, T. K. (editor)

1999 The Hurricane Hill Site (41HP106): The Archaeology of a Late Archaic/Early Ceramic and Early Middle Caddoan Settlement in Northeast Texas. 2 Vols. Special Publication No. 4. Friends of Northeast Texas Archaeology, Pittsburg and Austin.

2005 Archenlngical Investigations at the Pilgrim's Pride Site (4ICP304), a Titus Phase Community in the Big Cypress Creek Basin, Camp County, Texas. 2 Vols. Report of Investigations No. 30 . Archeological \& Environmental Consultants, LLC, Austin.

2008 The Archeology of the Roitsch Site (41RR I6), an Early to Historic Caddo Period Village on the Red River in Northeast Texas. In Collected Papers from Past Texas Archeological Society Summer Field Schools, edited by T. K. Perttula, pp. 313-628. Special Publication No. 5. Texas Archeological Society, San Antonio.

Pertula, T. K., M. R. Miller, R. A. Ricklis, D. J. Prikryl, and C. Lintz

1995 Prehistoric and Historic Aboriginal Ceramics in Texas. Bulletin of the Texas Archeological Societ 66:175-235.

Perttula, T. K., M. B. Trubitt, and J. S. Girard

2012 The Use of Shell-Tempered Pottery in the Caddo Area of the Southeastern United States. Southeastern Archaeology 30(2):242-267.

Prikryl, D. J.

2008 The 1991 and 1992 Texas Archeological Society Field School Excavations at the Fasken Site (4IRR 14), Red River County, Texas. In Collected Papers from Past Texas Archeological Snciety Summer Field Schools, edited by T. K. Perttula, pp. 125-171. Special Publication No. 5. Texas Archeological Society, San Antonio.

Rice, P. M.

1987 Pottery Analysis: A Suurcebook. University of Chicago Press, Chicago.

1996 Recent Ceramic Analysis: 1. Function, Style, and Origins. Journal of Archaeological Research $4(2): 133-163$.

Rohrbaugh, C. L.

1973 Hugo Resenvir III: A Report on the Early Formative Cultural Manifestations in Hugo Reservoir and in the Caddoan Area. Archaeological Site Report No. 24. Oklahoma River Basin Survey, University of Oklahoma Research Institute, Norman, Oklahoma.

Schambach, F. F.

1982 An Outline of Fourche Maline Culture in Southwest Arkansas. In Arkansas Archeology in Review, edited by N. L. Trubowitz and M. D. Jeter, pp. 132-197. Research Series No. 15. Arkansas Archeological Survey, Fayetteville.

1998 Pre-Caddoan Cultures in the Trans-Mississippi South: A Beginning Sequence. Research Series 53. Arkansas Archeological Survey, Fayetteville.

Schambach, F. F. and J. E. Miller

1984 A Description and Analysis of the Ceramics. In Cedar Grove: An Interdisciplinary Investigation of a Late Caddo Farmstead in the Red River Valley, edited by N. L. 'Trubowitz, pp. 109-170. Research Series No. 23. Arkansas Archeological Survey, Fayetteville. 
Skinner, S. A., R. K. Harris, and K. M. Anderson (editors)

1969 Archaeological Investigations at the Sam Kaufman Site, Red River County, Texas. Contributions in Anthropology No. 5. Southern Methodist University, Dallas.

Story, D. A.

2000 Introduction. In The George C. Davis Site, Cherokee County, Texas, by H. P. Newell and A. D. Krieger, pp. 1-31. $2^{\text {nd }}$ Edition. Society for American Archaeology, Washington, D.C.

Suhm, D. A. and E. B. Jelks (editors)

1962 Handbook of Texas Archeology: Type Descriptions. Special Publication No. 1, Texas Archeological Society, and Bulletin No. 4, Texas Memorial Museum, Austin.

Teltser, P. A.

1993 An Analytic Strategy for Studying Assemblage-Scale Ceramic Variation: A Case Study from Southeast Missouri. American Antiquity 58(3):530-543.

Turner, E. S., T. R. Hester, and R. L. McReynolds

2011 Stone Artifacts of Texas Indians. $3^{\text {rd }}$ Edition. Taylor Trade Publishing, Lanham, Maryland.

Wyckoff, D. G. and L. R. Fisher

1985 Preliminary Testing and Evaluation of the Grobin Davis Archeological Site, 34Mc-253, McCurtain County, Oklahoma. Archeological Resource Survey Report No. 22. Oklahoma Archeological Survey, Norman. 